\title{
THE EFFECT OF THE PRIVATE FOUNDATION PROVISIONS OF THE TAX REFORM ACT OF I969 ON COMMUNITY DEVELOPMENT CORPORATIONS
}

\author{
JoRDAN D. LUTTRELI*
}

Ambrose Bierce defined a lawyer as "[o]ne skilled in circumvention of the law,"1 and it seems likely that it was a similar view of certain exempt organizations which led Congress to enact the "private foundation" provisions of the Tax Reform Act of $1969 .^{2}$ The 1965 Treasury Report on Private Foundations had set forth convincingly and at length both the failure of privately controlled foundations to police their own activities, and the law's incapacity to cope with the abuses found to exist. ${ }^{8}$

Private foundations are typically established as nonprofit corporations under state law and, along with other qualifying organizations, may obtain an exemption from federal income taxation under section 501 (c) (3) of the Internal Revenue Code of 1954 because they are organized and operated for certain exempt purposes, principally those involving charitable, educational, scientific, or literary pursuits. With a few narrow exceptions organizations so exempt (whether private foundations or not), may accept contributions which are deductible to their donors under section i70. The conclusion of Congress evidenced in the Tax Reform Act was that many private foundations, while affording their financial supporters a tax deduction, were not using those contributions for the stated exempt purposes. Although prior law had provided for sanctions in certain extreme cases, it had not proved capable of dealing effectively with abuses on a lesser scale. The private foundation provisions of the Act attempt to remove that inadequacy by utilizing a series of graduated taxes to discourage private foundations from engaging in any of several kinds of activities viewed as improper. Congress cannot be said to have had community development corporations (CDC's) in mind when it enacted the private foundation provisions. Nevertheless, any CDC exempt under section 501 (c) (3), as every other exempt organization, must gauge what impact the private foundation provisions will have on its operations. In addition, a CDC not yet exempt but contemplating the submission of an application for exemption to the Internal Revenue Service will wish

\footnotetext{
- Supervising Attorney, National Housing and Economic Development Law Project, Earl Warren Legal Institute, University of California, Berkeley.

The research reported herein was performed pursuant to a grant with the Office of Economic Opportunity, Washington, D.C. 20506. The opinions expressed herein are those of the author and should not be construed as representing the opinions or policy of any agency of the United States Government. I wish to thank Professor Lawrence M. Stone, Kenneth F. Phillips, Esq., and David M. Madway, Esq., for their criticisms of this article in manuscript. The article itself is a shortened version of a chapter to appear in a manual on economic development in preparation at the Project. Those interested in receiving the longer version may write the author.

${ }^{1}$ A. Bierce, The Deviz's Dictionary 75 (Dover ed. I958).

${ }^{2}$ INT. REv. CODE OF I954 $\$ \$ 507-09,4940-48$.

${ }^{8}$ U.S. Treasury Dep't, Report on Private Foundations (Comm. Print 1965).
} 
to weigh the advantages of exempt status against the potential adverse impact of the provisions.

The term "community development corporation," or CDC, has been used to describe organizations carrying on a great variety of activities, ranging from CDC's concerned solely with educational and social matters on the one hand, to those involved in all types of financing and commercial arrangements and technical and management assistance on the other. All CDC's, however, do share one common characteristic: they are broad-based membership organizations with members (or shareholders) who exclusively or for the most part are poor and live or work in a particular geographic area. The type of CDC to which this article is addressed is one which engages in activities that are more economic in nature, rather than social or service oriented, since in general the greater the commercial and financial activities of a CDC, the more likely it will be that those activities may be adversely affected by the Act. Thus, the type of CDC discussed in this article is one which is or plans to be involved in a full range of the following activities: investing in or making loans to individually or community-owned enterprises, setting up its own businesses as internal divisions or subsidiaries, entering into joint ventures, putting up guaranty money, providing all types of management and technical assistance, and arranging for all of the foregoing from other sources. ${ }^{4}$

In many cases the CDC is incorporated as a nonprofit corporation under applicable state law, ${ }^{5}$ and has either obtained an exemption from federal income taxation under section $50 \mathrm{I}$ (c) (3) of the Internal Revenue Code, or will be considering doing so. Several benefits are gained by taking advantage of the exemption. With an exemption, the CDC is in a much improved fund-raising position. It will be better able to secure charitable contributions from individuals and corporations, since contributions to an organization exempt under section 5 or (c) (3) are deductible to the donor within the limits specified in section I70 of the Code. The CDC's ability to obtain money from other exempt organizations will also be enhanced. ${ }^{\bullet}$ Such other organizations are most obviously acting for exempt purposes and are consequently

\footnotetext{
This article assumes that the CDC will be able to obtain an exemption if it wishes to do so. The CDC may find this to be no easy task for several reasons. First, the Service has not issued any revenue rulings in this area, so that its position is difficult to determine. Second, in those private rulings which have been issued, the Service has imposed restrictions which a CDC may not wish to accept. Third, the Service may be concerned that excessive private benefit will redound to those assisted by a CDC, although this fear should not be substantial where the CDC retains control over the businesses assisted. In such a case, returns from the business will go to the $C D C$, which will likely be governed by articles which forbid the inurement of any benefit to individuals.

'Some CDC's are formed as for-profit corporations, issuing voting shares exclusively or principally to the community it serves. As such, they would not be able to apply for a section 501 (c) (3) exemption, since their net earnings could "inure to the benefit of any private shareholder," a consequence prohibited by the section.

${ }^{\circ}$ Over $90 \%$ of foundation grants (in dollars) reportedly go to exempt organizations. Hearings on H.R. 13270 Before the Senate Comm. on Finance, 91st Cong., Ist Sess., pt. 6, at 6I44 (I969) (H.R. 13270 was the House version of the Tax Reform Act). An Internal Revenue Service Blue Book lists those organizations to which deductible contributions may be made. Eighty-one per cent of all foundations are said to make grants only to these qualified organizations. Id. at 6165 .
} 
minimizing the risk of jeopardizing their own exemptions by making contributions (usually termed "grants") to exempt organizations. ${ }^{7}$ Exempt organizations may also escape a host of state and local taxes and licensing requirements. ${ }^{8}$ The advantages of the exemption, however, must be viewed with its attendant disadvantages, one of which is the potentially unfavorable impact of the private foundation provisions of the Tax Reform Act of 1969 .

The Tax Reform Act of $I 969$ is unquestionably the most significant piece of tax legislation since the revision of the Internal Revenue Code in 1954. Approximately one-quarter of the Act is devoted to remedying what Congress viewed as the unacceptable practices of private foundations. In gauging the effect these provisions will have on CDC's, two questions must be answered. Will a CDC be considered a "private foundation"? If so, what provisions restricting the activities of all private foundations will be of practical importance to it?

Generally, every section 5 or (c) (3) organization, including a CDC, is presumed to be a "private foundation" unless it can demonstrate that it is "publicly-supported" to a substantial extent, and thus classified as a "public charity." There are basically two ways a CDC can establish itself as a "public charity." One is to demonstrate that under either of two similar tests more than one-third of its financial support is derived from "public sources." "Public sources" may generally be defined as any governmental source, other "public charities," and, within certain dollar or percentage limits per contributor, the general public. A CDC may also demonstrate that it is a "public charity" and not a "private foundation" in a second way: by satisfying a "facts and circumstances" test found in the Regulations which stresses factors other than public financial support. These factors include the organization's fund-raising activities and the extent to which it is controlled by the public and makes its facilities and programs available to it.

A genuinely broad-based CDC will most likely be able to meet one of these tests. If the tests are not met, however, what disabilities will a CDC that has been found to be a "private foundation" suffer that a CDC which qualifies as a "public charity" will escape? In general, a private foundation will be potentially subject to six taxes: an excise tax based on investment income and initial and additional taxes on self-dealing, failure to distribute income, excess business holdings, investments which jeopardize charitable purpose, and taxable expenditures. ${ }^{0}$ Except for the tax on investment income, all of these taxes are in effect graduated penalties designed to discourage a private foundation from acting in certain ways. Since most of a CDC's activities are not of the types which are intended to be discouraged, the typical CDC will have little to fear even if it finds itself a private foundation.

\footnotetext{
The Tax Reform Act, moreover, requires "private foundations" to make minimum distributions of income for qualified purposes. INT. REv. CODE of I954 \$4942. Distributions to other exempt organizations probably satisfy these distribution requirements most easily. See part III infra.

${ }^{8}$ See, e.g., CaL. Rev. \& TAX. CODE $\$ 23701$ (West 1970).

${ }^{\circ}$ INT. REv. CODE OF 1954, $\$ \$ 4940-46$.
} 


\section{Avoiding Private Foundation Status}

Rather than define what a private foundation is, the Code declares what it is not. Section 509, which defines "private foundation," states at the outset that all section 501 (c) (3) organizations are private foundations ${ }^{10}$ and then proceeds to establish four exceptions to this general rule. Those section $5^{\mathrm{Or}}$ (c)(3) organizations not fitting into the exceptions are "private foundations" and are subject to the disadvantages to be discussed subsequently. Only two of the four exceptions will be of utility to a CDC attempting to escape private foundation status. ${ }^{11}$

One of the exceptions of which a CDC may take advantage in effect incorporates two tests which have forerunners in post-1966 Regulations: one of the public financial support tests and the facts and circumstances test. ${ }^{12}$ As were their predecessors, these new tests, found in the section ryo Regulations are designed to distinguish between "publicly-supported" organizations and all other exempt organizations. The Code since I964 has allowed a deduction for contributions of up to thirty per cent (now fifty per cent) of an individual's adjusted gross income made to "publicly-supported" organizations, while imposing a twenty per cent limit on contributions to all other exempt organizations. ${ }^{\mathbf{1 3}}$ These tests will now take on further importance because any organization meeting them will not only be excluded from the definition of a private foundation, but will also be able to receive contributions of "increased" deductibility by the contributors.

The other exception available to a CDC seeking to avoid private foundation status sets forth a second public financial support test. ${ }^{14}$ This test somewhat more broadly defines public financial suppport in order to exclude from private foundation status those organizations which may have had some difficulty fitting within the

\footnotetext{
${ }^{10}$ In a separate section churches and related groups are automatically excluded from even the presumption that they are private foundations and thus do not have to attempt to fit within one of the four exceptions. INT. REv. CODE OF I954 $\$ 508$ (c)(I). Authority is delegated to the Treasury, in addition, to exclude in its discretion certain educational institutions and other organizations from the presumption, the latter on the criterion of "efficient administration." INT. REv. CODE OF I954 $\$ 508$ (c)(2)(B).

${ }^{11}$ INT. REv. CODE of $1954 \S 509$ (a)(I) and (2). Of the two exceptions not of importance to a CDC, one is designed for organizations established to support other "public charities," and the other for organizations testing for public safety. INT. REv. CODE OF I954 $\$ 509$ (a)(3) and (4).

${ }^{19}$ INT. Rev. CODE of I954 $\$ 509$ (a)(I) referring to INT. REv. CODE OF I954 $\$$ I7o(b)(I)(A)(i)-(vi). The tests have only very recently been proposed by the Service and apply to all taxable years beginning after December 3I, r969. Proposed Treas. Reg. $\$$ I.I70A-9, 36 Fed. Reg. 9298. (I97I). The old tests upon which they are based in large part are applicable to taxable years beginning prior to January $I$, I970, and can be found in Treas. Reg. $\$$ I.I70-2(b)(5)(iii)(b) \& (c) (r966).

${ }^{13}$ The $30 \%$ limit was raised to $50 \%$ by the Act, while the $20 \%$ limit was left unchanged. INr. Rev. CODE of $1954 \$ 170(b)(x)$. The statement in the text is subject to some refinement and qualification. The standard of adjusted gross income referred to is not quite accurate, as the $50 \%$ limit applies to an individual's "contribution base," which is defined as adjusted gross income computed without regard to any net operating loss carry-back to the taxable year. INT. REv. CoDE of I954 $\$$ I7O(b)(r)(F). For limitations on contributions of certain capital gain property, see INT. REv. CoDE OF I954 $\$$ I70(b)(I) (D). It should also be noted that the $50 \%$ limit applies only to individuals; corporations may only deduct up to $5 \%$ of their taxable income, with certain modifications. INT. REv. CODE of I954 $\$$ I70(b)(2).

14 INT. REv. CODE OF $1954 \$ 509$ (a) (2).
} 
forerunners of the other tests, but which were not engaging in the kinds of activities which led Congress to enact the private foundation provisions. ${ }^{15}$

The two public financial support tests follow roughly the same outline, and a CDC which can qualify under one will no doubt be able to qualify under the other, at least while the CDC is primarily dependent upon outside funds rather than those generated from its own operations. If the CDC cannot demonstrate the requisite public financial support to qualify under either of these tests, it still may qualify under the facts and circumstances test, which requires a lesser showing of public financial support, and in rare instances may not require any such showing at all. A CDC should first attempt to qualify under one of the public financial support tests, however, since these standards are more mechanical in nature than those of the facts and circumstances test. As its name rightly implies, the facts and circumstances test involves a greater subjectivity in application, an application made, moreover, by the Service, not by the organization. Before turning to a discussion and comparison of the three tests, it will be of some value to set forth brielly the history of the section I70 tests, because without some explanation their incorporation by reference in section 509(a) (x) is not readily understandable.

\section{A. The History of the Section 170 Tests}

After defining a "private foundation" as any section 501 (c)(3) organization, section 509 then first excludes those organizations to which individuals can make deductible contributions of up to fifty (formerly thirty) per cent of their adjusted gross income, as opposed to twenty per cent for other organizations. Of all the former "thirty per cent" organizations, only one is of relevance to a CDC. ${ }^{16}$ Termed a "publicly-supported" organization in the Regulations, its statutory definition is:

an organization referred to in [section $5 \circ(c)(3)]$ which normally receives a sub. stantial part of its support . . . from a governmental unit . . . or from direct or indirect contributions from the general public ....17

This provision was the ultimate result of proposals in President Kennedy's $\mathrm{Ig} 63$ Tax Message to Congress in which he sought to extend more favorable treatment to those charitable organizations "which are publicly supported and controlled ...."18

\footnotetext{
${ }^{15}$ S. REP. No. 552, 9ist Cong., Ist Sess. 56 (xg69) [hereinafter referred to as SENATE Repont]. Organizations escaping private foundation status under this test may also receive contributions which are deductible up to $50 \%$ of an individual's "contribution base." INT. REv. CoDe of $x 954 \$ \times 70$ (b)(I)(A) (viii).

${ }_{26}$ The others consist of churches and educational organizations, including certain related groups, and hospitals and governmental units, and thus would rarely if ever be of pertinence to a CDC. Even if a CDC carried on some educational activities, it would not be considered an educational organization, and thus a "thirty per cent" organization, since the definition in the Regulations excludes "organizations engaged in both educational and noneducational activities unless the latter are merely incidental to and growing out of the educational activities." Treas. Reg. $\$$ I.x70-2(b)(3)(i) (1958).

${ }^{17}$ INT. REv. CODE OF I954 $\S \mathrm{I} 7 \mathrm{O}$ (b)(I)(A)(vi). Although the reference in the statute is to section $I 70(c)(2)$, the language of that section is virtually identical to that of section 501 (c)(3), and the few differences which do exist are immaterial to a discussion of CDC's.

${ }^{18}$ Liles, Qualification of Museums and Similar Institutions as Publicly Supported Organizations, 45 TAXES 528 (1967).
} 
The provision as ultimately enacted, however, made no reference to public control, but only to "public support." Public support was said in the House Report to be public financial support, exclusive of other types of public support or involvement. The significance of this difference in terminology is uncertain. The explanations in the House Report suggested that, although the notion of public financial support was a central consideration, organizations which served the public, or a particular portion of the public, or which were controlled by it, were also to be considered "publicly-supported."19 Thus, examples were given of organizations such as museums, libraries, civic centers, and community chests, all of which seem to exemplify service to and control by the public as much as financial support from it.

In the first of what proved to be three steps eventually leading to the issuance of final Regulations designed to implement the provision, the Service provided only for a public financial support test, which basically required that more than one-third of an organization's total financial support be drawn from the public. ${ }^{20}$ Substantial pressure to expand the Regulations' scope was then apparently placed on the Service by organizations which served and were controlled by the public, but which foresaw difficulty in demonstrating the requisite public financial support because of their reliance on large gifts and endowments from a limited number of individuals. ${ }^{21}$ As a consequence, a facts and circumstances test was added to the final Regulations which, though bowing in the direction of public financial support, allowed much greater emphasis to be placed on other factors in determining whether an organization was "publicly-supported." Incorporation of these factors in the facts and circumstances test swung the emphasis away from the sources-of financial support toward public service and control.

The new section I7o Regulations follow the same outline established by the Regulations issued in $\mathrm{Ig} 66$ in that both a public financial support and a facts and circumstances test are maintained. Some modifications have been made in both tests, however. These were apparently designed to dove-tail the new section I70 tests with the public financial support test added by the Tax Reform Act in section 509(a) (2), which has been further explained and developed in proposed Regulations issued by the Service in late $1970 .^{22}$ Since the public financial support tests are basically similar to one another, they will be discussed simultaneously despite their varied history. Subsequently, the facts and circumstances test will be examined.

\section{B. The Public Financial Support Tests}

In general the public financial support tests require that to be considered a public charity (rather than a private foundation) an organization must derive at

\footnotetext{
${ }^{10}$ Id. at 529 .

${ }^{20}$ See Rev. Pub. 66-I00, I966-I CuM. Bulz. 5I.

21 Liles, supra note 18 , at 530 .

22 The passage of the Tax Reform Act has imposed an enormous burden on the Service merely in requiring the issuance of Regulations implementing the Act's provisions. After approximately eighteen months, the Service issued proposed Regulations on all three tests, and set June 28 , 197I, as the date on which hearings will be held on them. 36 Fed. Reg. 9298 (I97I).
} 
least one-third of its total support from public sources. With one important exception, the definition of public support and total support are roughly the same in both the section 509 (a) (2) and the section 170 tests. Both tests establish procedures pursuant to which an organization may ask the Service for a determination of whether it is a private foundation or a public charity at the organization's inception. The new tests, thus, are a substantial improvement over the old public financial support test which required that an organization have been in existence for five years before it could seek a determination under the test. ${ }^{23}$ The section 509 (a) (2) test provides for the exclusion of unusual grants in certain instances, the counterpart of which is found in the new facts and circumstances test rather than in the section r7o public financial support test. Lastly, the section 509 (a) (2) test imposes a one-third limit on the amount of total support which may be accounted for by investment income, and in this respect is more restrictive than the section I 70 tests, which set no investment income limits.

Aside from gross receipts, the tests' definitions of support are identical, and include as their more important categories gifts, grants, contributions, membership fees, net income from business activities unrelated to the organizational purposes, and gross investment income. ${ }^{24}$ Gross receipts are included in the statutory definition of support in section 509(d), but are excluded under section $x 70$. These receipts are defined as income derived from admissions, sales of merchandise, performance of services, or furnishing of facilities in any activity which is related to the purposes for which the organization was declared exempt. This difference, though insignificant while a CDC remains dependent on outside sources of funds, may gain in importance as the CDC weans itself from those sources and becomes self-supporting.

The tests' definitions of public support are also basically the same (with the same exception for gross receipts), although some differences do exist which may make the section 170 test more attractive in borderline cases where the organization's public support is very close to the minimum one-third floor imposed by both tests. ${ }^{25}$ Both tests include in public support only public gifts, grants, contributions and membership fees, and, in the section 509(a) (2) test, certain gross receipts. Excluded altogether are investment and unrelated business income, and other income included in total support, as well as that income, such as capital gains, which is specifically excluded from total support.

\footnotetext{
${ }^{23}$ See Treas. Reg. \$I.170-2(b)(5)(ii)(c)(r) (x966).

${ }^{24}$ Both tests refer to the statutory definition of support found in section 509 (d). The section I70 test reference expressly excludes gross receipts. Proposed Treas. Reg. \$1.170A-9(e)(7), 36 Fed. Reg. 9303 (1971); Proposed Treas. Reg. $\$ 1.509$ (a)-3(a) (2), 35 Fed. Reg. 17846 (1970). The definition of support also includes two other categories which should usually be of lesser importance: tax revenues lcvied for the benefit of the organization and either paid to it or expended on its behalf, and the value of services or facilities especially furnished by any governmental unit without charge. INT. REV. CODE OF r954 $\$ 509(d)(5)$ and (6). Specifically excluded from the definition of support, which is otherwise not limited, are capital gains and the value of any tax exemption or similar benefit. Id. $\$ 509$ (d).

${ }^{25}$ Public support is defined in Proposed Treas. Reg. $\$$ 1.170A-9(e)(6), 36 Fed. Reg. 9303 (197I) and INr. REv. CODE of r954 $\S 509(\mathrm{a})(2)$. The latter definition is further explained in Proposed Treas. Reg. $\S$ r.509(a)-3(a) and (b), 35 Fed. Reg. I7845-46 (1970).
} 
Under the section 509 (a) (2) test, public sources are governmental units, those public charities which have already satisfied one of the section I7o tests, and those contributors not considered "disqualified." The entire amount of gifts, grants, contributions, and membership fees from such sources are included in public support. Gross receipts are subject to the additional restriction, however, that they may not exceed one per cent or $\$ 5,000$ (whichever is greater) from any one source, even though that source is public. ${ }^{26}$ Gifts, grants, contributions, membership fees, and gross receipts are totally excluded if derived from "disqualified persons," principal among which, for purposes of fund raising, are contributors or grantors who have donated amounts in excess of either $\$ 5,000$ or two per cent (whichever is greater) of the organization's total support in a taxable year. ${ }^{2 \pi}$

The section r7o public financial support test includes in public support all funds obtained from governmental units and other section 170 organizations. Its treatment of donations from individual and corporate contributors, however, is slightly different. The section I70 test includes all such individual and corporate contributions, regardless of source, but only to the extent of two per cent of the organization's total support. Thus, the section I70 test is somewhat more liberal in that it does not entirely exclude those contributions from the equivalent of substantial contributors, but includes them up to a maximum of two per cent of total support. In a borderline case this difference might be sufficient to allow an organization to qualify under the section I7o test even though it would not satisfy the section 509 (a) (2) test.

Those CDC's which are largely or totally supported by funds from government programs will obviously have no difficulty qualifying as a public charity under either of the public financial support tests, since funds from a governmental unit are considered to be public in nature. ${ }^{28}$ Thus grantees under either the Special Impact program of the Office of Economic Opportunity or the Model Cities program of the Department of Housing and Urban Development would be classified as public charities under either of the two tests. For a CDC not so fortunate as to receive

\footnotetext{
${ }^{20}$ Because of this added limitation on gross receipts, the section 509 (a)(2) regulations devote a great deal of space to the proper distinctions between gross receipts on the one hand, and gifts, grants, contributions, and membership fees on the other. Proposed Treas. Reg. $\$$ r.50g(a)-3(f) to (h), 35 Fed. Reg. I7849-50 (I970).

${ }^{37}$ For a further discussion of "disqualified person" see notes 76-9r infra and accompanying text. In general there are three types of disqualified persons: substantial contributors, foundation managers, and government employees.

${ }^{28}$ In some unsual cases a problem might arise in distinguishing between grants and gross receipts. The distinction maintained by the Regulations is that between the use of funds to benefit the grantor directly and their use to benefit the public in general. Typically, of course, a grant from a government agency to a CDC is for the purposes of benefitting the community which the CDC serves and is not intended to benefit the federal government directly. See Proposed Treas. Reg. $\$ 1.509(\mathrm{a})-3(\mathrm{~g})$, particularly example (3), 35 Fed. Reg. I7849-50 (1970).

If the CDC finds that it is in a position to choose between one of the two tests, it should qualify under section $x^{2}$, since grants which it makes in turn to its grantees will be considered to be from it as a public charity. It can thereby assist its own grantees in attempting to become public charities themselves. See INT. Rev. CoDE of $1954 \S 509$ (a) (2); Proposed Treas. Reg. $\$ 1.509$ (a)-3(j), 35 Fed. Reg. I785I (I970); Proposed Treas. Reg. §I.I70A-9(e)(6)(i), 36 Fed. Reg. 9303 (I97I).
} 
government largesse, there are still a number of other sources to which it may turn. Principal among these are its own community, foundations, corporations, and wealthy individuals. If it does so, however, it may encounter problems when attempting to meet either of the public financial support tests. If the CDC is successful in deriving a substantial amount of its funds from the community itself, then it will stand a good chance of meeting the tests. This is because the CDC will be obtaining many contributions of relatively small amounts from numerous contributors, and all of this money will be includable in public support. Similarly, where the CDC is fortunate enough to receive a substantial portion of its funds from other publicly-supported organizations which themselves have qualified under one of the section I70 tests (such as the United Fund or those rare national foundations which depend upon relatively small contributions from large memberships), it will be able to qualify under either of the public financial support tests. Where the CDC is dependent upon foundations, corporations, or wealthy individuals, however, its chances of qualifying will be substantially reduced. With few exceptions all of the national foundations which have been active in making economic development grants to CDC's are themselves private foundations, not public charities. If their contributions exceed the greater of $\$ 5,000$ or two per cent of the CDC's total support, the foundation, corporation, or individual will be considered a substantial contributor, and the contribution completely excluded from the category of public support under the section 509(a)(2) test. Under the section I70 public financial support test, the CDC will be somewhat better off, in that amounts up to two per cent of total support, even though from such "tainted" sources, can be included in public support. Obviously, however, if the CDC is dependent on one, or even a handful, of such large contributors, the two per cent amounts will not total up to the minimum one-third public financial support.

A CDC which finds itself unable to qualify under either of the public support tests has open to it two other alternatives which it may pursue before resigning itself to private foundation status. First, the CDC may attempt to qualify under the facts and circumstances test recently proposed in the Regulations issued by the Service under section I70. Second, it might attempt to exclude those large contributions from "tainted" sources pursuant to the unusual grant exclusions found both in the section 509 (a) (2.) test and in the facts and circumstances test.

\section{The Facts and Circumstances Test}

The facts and circumstances test recently proposed by the Service under section I70 generally follows the pattern established by its predecessor. ${ }^{20}$ By continuing to provide for this kind of test, the Service recognizes that the organizations to which Congress addressed itself in the Act were those over which the public at large has little control. Principally, Congress was concerned with those small "family" founda-

${ }^{29}$ The new test is set forth in Proposed Treas. Reg. $\$$ I.I70A-9(e)(3), 36 Fed. Reg. 9300 (I97x). The old test may be found in Treas. Reg. $\$ 1.170-2(b)(5)$ (iii)(c) (rg66). 
tions established by an individual for tax, rather than charitable reasons, and over which that individual exercised effective control. It was also concerned with certain of the larger national foundations which were originally formed through endowments provided by enormously wealthy individuals and which now exercise virtually complete control over their own operations as self-perpetuating bodies. The public financial support tests offer a shorthand method for separating truly public charities from such private foundations. The absence of public financial support, however, does not necessarily establish the presence of private control. Some organizations, even though not publicly supported financially, still are not controlled by the "private" sources from which they derive their funds. It is inappropriate for such organizations to be subject to the private foundation provisions found in the Tax Reform Act, since they do not engage in the type of activities which prompted congressional concern. The facts and circumstances test provides an escape hatch through which such organizations, although unable to demonstrate the requisite public financial support needed to meet the public financial support tests, can still avoid private foundation status by demonstrating that they are controlled by the public and are responsive to it. ${ }^{30}$

An examination of the test itself reveals that some showing of public financial support is still demanded through the requirement that at least ten per cent (rather than one-third) of the organization's support comes from public sources. ${ }^{31}$ The inclusion of some mention of public financial support seems necessary, given the statutory language of section I7o that the organization must receive a "substantial part of its support . . . from a governmental unit . . . or from direct or indirect contributions from the general public ...."32 In addition to the ten per cent requirement, the test sets forth one additional requirement and then several factors which, although not mandatory, will, taken together, have a substantial bearing on whether the organization satisfies the test.

\footnotetext{
${ }^{30}$ The Service appears to be recognizing that a community foundation (such as a CDC) may be public in nature regardless of its sources of financial support. The Assistant Secretary in charge of tax policy in the Treasury, John Nolan, has recently stated, "A [public financial] support test is not appropriate to determine whether the community foundation is a public charity under $\S I_{70}(\mathrm{~b})(\mathrm{I})(\mathrm{A})$. The typical community foundation is intended to provide endowment funds for community institutions and future community needs, so that current contributions become a progressively smaller part of its total receipts, but at the same time it has received its support from the general public and is as responsive to the public as we need require for public charity status. Accordingly, we are developing a test based on such factors as a continuous program of solicitations of additional endowiment funds, receipt of a substantial number of independent gifts over its history from unrelated parties, control by a representative group from the community periodically reappointed, and absence of control by any single individual or family." 9 Non-Profit Organ. Tax Letter, No. 4, at 2 (Mar. 8, I97I).

${ }^{31}$ Proposed Treas. Reg. $\$$ r.I70A-9(e)(3)(i), 36 Fed. Reg. 9300 (I97I). In the first facts and circumstances test no floor was expressly required in percentage terms, although both the test itself and the examples illustrating it suggested that some public financial support would be required for an organization to qualify.

${ }^{32}$ INT. REv. CODE of I954 $\$ I 70(b)(I)(A)(v i)$. The Service's decision to employ a definite percentage figure may be questioned as inserting rigidity into a test which was initially designed to encourage a great deal of Alexibility. The Service may have retained the desired flexibility, however, through its provision for the exclusion of unusual grants, while introducing an element of objectivity into the test through the use of the $10 \%$ minimum.
} 
The test also requires that the organization must continuously attempt to attract additional support from public sources. ${ }^{33}$ These fund-raising efforts can be met either through actual solicitation or merely through the activities which the organization carries on, if those activities are designed to attract support from governmental units or other public charities. Most CDC's would seem to meet this requirement simply through their activities since, regardless of whether their outside sources of financing are foundations, corporations, individuals, or the government, in general their ultimate aims are the same-large scale community involvement in the development, establishment, and maintenance of community-owned enterprises. As added assurance, however, the CDC may wish to engage in formal fund raising.

The most obvious of the several "optional" factors states that the closer the organization comes to the one-third public support figure, the greater will be its chances of meeting the facts and circumstances test. Thus, an organization receiving the bare minimum ten per cent public financial support will be viewed less favorably than the organization receiving thirty per cent. ${ }^{34}$ The organization's attempt to meet the test will also be viewed more favorably if it is dependent upon a number of fairly substantial gifts from unrelated persons, rather than grants from members of a single family. In addition, the governing body of the organization will be examined in order to determine whether its representatives are selected by only a few people or, in contrast, reflect the interests of the general public. In the case of a membership organization such as the typical CDC, election of the directors by a broadly-based membership is preferable. Those not directly elected by the membership should represent the public at large-such as elected public officials, civic leaders, or persons representing the views of a broad cross-section of the community-or have gained their place on the board by virtue of their expertise. The organization should also make its facilities or services available to the public and should allow the public to participate in its programs and policies. ${ }^{35}$ In the case of a membership organization such as a CDC, there are several other factors which will also be taken into account: whether dues-paying members are solicited, whether the amount of dues required is fixed sufficiently low to encourage a broad-based membership, and whether the organization's activities will likely appeal to those whom the organization intends to serve.

It is certain that a genuinely broad-based CDC will easily meet all of the nonfinancial factors mentioned in the facts and circumstances test which are concerned with the organization's public control and responsiveness. The only difficulty which may be encountered is the public nature of the funds upon which the CDC depends, a matter which in most cases is outside the control of the CDC.

\footnotetext{
${ }^{33}$ Proposed Treas. Reg. § I.I70A-9(e)(3)(ii), 36 Fed. Reg. 9300 (r97I).

${ }^{34}$ These factors are set forth in Proposed Treas. Reg. $\$$ I.x70A-9(e)(3)(iii)-(vii), 36 Fed. Reg. 9300-01 (r97I).

${ }^{35}$ Of particular importance to CDC's is one of the factors which the Service will consider as evidence of an organization's public support maintenance of a definitive program to accomplish charitable work in the community such as slum clearance or development of employment opportunities. Proposed Treas. Reg. §I.I70A-9(e)(3)(vi)(c)(2), 36 Fed. Reg. 9301 (I97I).
} 
It is the Service which will ultimately be responsible for making a determination under the facts and circumstances test, and hopefully it will keep the financial predicament of some CDC's in mind when doing so. Flexibility could be achieved through use of the unusual grant exclusion provided for in both the facts and circumstances test and the section 509 (a)(2) test. $^{36}$ Before the unusual grant exclusion is considered, however, it seems advisable to treat briefly the procedures proposed by the Service for calculating both the public and total support of an organization.

\section{Normality and the Unusual Grant Exclusion}

Both statutory provisions, section $I 70$ and section 509, require an organization to demonstrate that it normally receives the appropriate amounts of public support. All three tests interpret normally to mean aggregated over a four-year period. Though differing somewhat in detail, they do not require an organization to demonstrate annually that it has received the requisite amount of public support during that particular year. ${ }^{37}$ The tests also make provision for those organizations which have not been in existence for four years and those organizations which have just come into existence and wish to secure rulings on their status in advance of beginning their operations. ${ }^{38}$

The basic consideration of the Service in issuing an advance ruling is whether it appears that the organization will in fact be a publicly-supported organization after it begins operation. In order to make this determination under section I70, the Service requests the organization to submit all the information which the organization would have submitted had it been attempting to meet the facts and circumstances test and, in addition, information on its anticipated sources of funds. The section 509 (a) (2) test sets forth factors which the Service will take into account should an organization apply for an advance ruling. Except for the addition of an investment income proviso (designed to determine whether the organization will meet the investment income test of section 509 (a) (2)), the factors there listed are similar in substance to those under section I70. There is apparently no definite advantage to an organization's attempting one test rather than the other.

It is definitely advantageous, however, for the organization to attempt to secure a favorable advance ruling. Once the organization has obtained the prior approval of the Service, moreover, it will be regarded as a public charity for a period of two years unless there is a prior public revocation of that status. The organization

\footnotetext{
${ }^{30}$ Although no reason is given for the absence of the unusual grant exclusion in the section I70 public support test, it may be that the Service believed that the availabilty of the exclusion in the facts and circumstances test was sufficient to insure the desired flexibility.

${ }^{37}$ Proposed Treas. Reg. $\S$ I.I7oA-9(e) (4), 36 Fed. Reg. 930 I (I97I); Proposed Treas. Reg. $\$$ I.509(a)3(c), 35 Fed. Reg. 17846 (1970). The particular four-year period may vary. Under the section I70 tests the four-year period is that of the four years immediately preceding the organization's current taxable year. In the case of the $\$ 509$ (a)(2) test the organization may choose between the immediately preceding four years, or its current taxable year and the immediately preceding three years.

${ }^{38}$ These methods are set forth in Proposed Treas. Reg. $\$$ r.r7oA-9(e)(4)(vii) and (5), 36 Fed. Reg. 9302-03 (I97I); Proposed Treas. Reg. $§$ I.509(a)-3(d) and (e), 35 Fed. Reg. 17848-49 (I970).
} 
which has secured a ruling will more likely be able to secure funds from other private foundations, since the latter will then not have to exercise expenditure responsibility over the grant and will probably be able to claim more easily that the amounts disbursed were made for qualified purposes under section 4942 of the Code. ${ }^{39}$ In addition, the organization itself will not be subject to the taxes which may be imposed on a private foundation engaging in certain prohibited activities.

An organization which fails to secure a prior ruling may attempt to qualify as a public charity at the end of its first taxable year. If it is unsuccessful in this attempt, it may again attempt to qualify at the end of its second year and if successful at that time, have any taxes imposed during its first taxable year abated. This procedure is not as satisfactory as attempting to secure an advance ruling. Not only does the organization subject itself to the possibility of taxes being imposed upon it (even though they may later be abated), but it may also find other private foundations reluctant to deal with it. Moreover, should the organizations fail to achieve public charity status at the end of its second year, it will be considered a private foundation for those two years and for all subsequent years until it can establish its public charity status. In comparison, an organization which receives an advance ruling stating that it is a public charity, unless notified earlier by the Service, will be considered a public charity for the first two years, even though it is unable to qualify at the end of that time. In such a case the organization will be considered a private foundation at the begining of the third year, but its status as a public charity will not be revoked retroactively. ${ }^{40}$

The exclusion for unusual grants permits modification of the usual procedures for determining whether an organization normally receives sufficient public support to meet either the section 509(a) (2) public support test or the facts and circumstances test. ${ }^{41}$ Although the mechanics of the exclusions vary somewhat, the underlying principle is the same. A grant which is unusual in size or is unexpected should not be included in determining whether an organization is publicly supported, since its inclusion would tend to distort the nature of the organization by overemphasizing an amount from only one source. ${ }^{42}$ This exception may prove particularly valuable to a CDC dependent upon private sources of support. By excluding one or two contributions, it may be able to achieve public charity status based on the public nature of its other sources of funds. This would be especially true where the CDC has

\footnotetext{
${ }^{39}$ For a discussion of expenditure responsibility and qualified distributions, see text accompanying notes 109-33 infra.

to There are two exceptions: taxes under $\$ 4940$ (the $4 \%$ tax on an organization's net investment income) and the determination of substantial contributors under $\$ 507$ (d) are retroactive.

${ }^{11}$ Proposed Treas. Reg. § I.I70A-9(e)(6)(ii) and (iii), 36 Fed. Reg. 9303 (r97r); Proposed Treas. Reg. $\$$ I.509(a)-3(c) (3) to (7), 35 Fed. Reg. I7846-47 (r970).

${ }^{2}$ It should be noted that the exclusion is available for more than one instance of an unusual grant, so that, an organization could exclude several grants over a period of time as long as it was able to convince the Service that all of the grants were unusual. Obviously, the greater the number of grants which the organization attempts to exclude, the more skeptical the Service will become of their alleged unusual nature.
} 
received most of its funds from a foundation, corporation, or individual that was instrumental in getting the CDC started, but which does not wish to exercise significant control over the organization's activities.

Under the section 509(a) (2) test, the year in which the unusual grant is made is simply excluded in calculating the normality of the organization's public support. An organization would normally be required to aggregate its public support and total support either from the four years immediately preceding its present taxable year or the three years immediately preceding its current taxable year plus that year itself. Under the mechanics of the unusual grant exclusion, normality would be based on a three-year rather than a four-year period. In the case of a newly-formed organization which has not applied for an advance ruling, the year in which the unusual grant was made can be excluded when, after two years, the organization attempts to establish that it is a public charity.

The mechanics in the facts and circumstances test are somewhat different. The amount of the unusual grant is simply omitted in the calculation of public support for the applicable period. The remainder of the support of the year in which the unusual grant is made is still included in the amounts aggregated over the appropriate period of time.

The rationale for the unusual grant exclusion is set forth in the Regulations applicable to the facts and circumstances test:

The exclusion .... is generally intended to apply to substantial contributions or bequests from disinterested parties, which contributions or bequests:

(a) Are attracted by reason of the publicly supported nature of the organization;

(b) Are unusual or unexpected with respect to the amount thereof; and

(c) Would, by reason of their size, adversely affect the status of the organization as normally being publicly supported . . . .43

Both tests expand on this rationale by setting forth several inquiries which are to be made. Was the grant made by a person who created the organization or has stood in a position of authority with respect to it? Has he previously made a substantial grant to the organization? Prior to receipt of the grant, was the organization relatively dormant or was it carrying on an active program? Similarly, prior to the year in which the unsual grant was made, had the organization met the public financial support tests or the facts and circumstances test of section I70? Was the contribution a bequest or an inter vivos transfer (the latter being viewed more favorably)? Lastly, was the grant made in the form of cash, liquid assets, or assets which further the organization's purposes, rather than a contribution of property which would tend to benefit the contributor more than the organization?

It can be seen that an unusual grant to a CDC should probably be excludable unless the CDC must rely upon it alone in order to undertake any activities whatsoever. In such a case, if the latter were true, the grant would not be excludable

\footnotetext{
${ }^{48}$ Proposed Treas. Reg. 5 I.x70A-9(c)(6)(ii), 36 Fed. Reg. 9303 (I97I).
} 
since it is likely that the organization was dormant prior to the grant. A similar problem might be raised where the amount of the grant is significantly larger than the amount of funds previously received by the CDC so that the nature of the CDC's operation is likely to change drastically. The Regulations do not indicate whether the mere size of a grant would in itself require the Service to disallow the exclusion of the grant. The Service may take the position that a grant will be excluded if it is unusual, but not if it is inordinately unusual. The language of the Regulations seems to imply that a grant could be excluded no matter what its size, so long as the grant does not "derogate from [the organization's] publicly supported nature and constitute a device to avoid the provisions of chapter 42 of subtitle D of this title [containing the provisions which tax certain proscribed activities of private foundations]."44 The Regulations go on to note that the exclusion of the unusual grant will be permitted "if no fundamental change has taken place in the normal broad, publicly supported nature of the organization or in its operations."

A CDC should be able to present a convincing case to the Service that, although the scope of its operations has changed, both its methods and its ultimate purposes have not. Thus, the CDC may argue that the exclusion of an unusual grant should be disallowed only if the grant would cause an organization formerly publicly controlled to fall into private hands. As long as the CDC continues to control its own activities, the unusual grant should be excluded since the CDC's public nature will be maintained. That public nature can be demonstrated by the CDC through the public contributions which it has already obtained from membership dues, public solicitations, public charities, and governmental agencies. The CDC should be able to couple its past fund-raising efforts with those which it will undertake in the future, pointing out to the Service that as a result of the increased power gained from the unusual grant, its chances for government funds and other kinds of public contributions are probably enhanced. ${ }^{45}$

\footnotetext{
"Proposed Treas. Reg. $\$ 1.509$ (a)-3(c)(4), 35 Fed. Reg. 17847 (1970).

45 Subsequent to the preparation of this article, the Service issued proposed Regulations which provide that an organization which qualifics as a community trust will be deemed to be publiclysupported. Proposed Treas. Reg. $\$$ I.I70A-9(e)(xo) to (19), 36 Fed. Reg. 19598 (I97I). The apparent purpose of the Regulations is to exclude from private foundation status those organizations which are publicly-controlled despite their financial dependence on a limited number of sources. CDC's should fit within the general intent of the Regulations. The CDC thus might attempt to qualify as a publiclysupported community trust by satisfying the detailed requirements of the Regulations, which rclate to the structure and administration of the organization, the nature of its support, and the character of its distributions. It should do so only as a last resort, however, since a community trust is precluded from undertaking certain activities which would subject it to taxation if it had private foundation status. For example, a community trust may not engage in acts which would amount to sclf-dealing under section $494 \mathrm{I}$ if it were a private foundation. Similarly, the trust may not possess holdings which would be excessive under section 4943. Among all of the penalty taxes of Chapter 42, the prohibitions of these two sections are those which a CDC would likely find most objectionable. Consequently, for most CDC's, a Service determination that the CDC satisfies one of the other tests (the mechanical test or facts and circumstances test) is more desirable than a finding that it qualifies as a community trust. On the other hand, most CDC's should find qualification as a community trust somewhat preferable to private foundation status.
} 
E. The Impact of Financial Independence

The above discussion of the three tests has presupposed a CDC depending on a few outside sources for its financial support. As has been seen, the nature of these sources alone as either public or private will very probably determine whether the CDC will meet either financial support tests and possibly the facts and circumstances test. Most CDC's rely on a limited number of such outside sources because of the difficulty of securing funds in any other fashion. Ideally, however, the CDC hopes that through a prudent use of those initial funds, it may wean itself and eventually become self-sustaining. If a CDC can successfully accomplish this feat, its eventual sources of financial support will be quite different from what they were initially. A crucial question, therefore, is whether a $\mathrm{CDC}$ will be considered a public charity when the bulk of its financial support comes from returns from its own business operations and its investments and loans in other businesses. ${ }^{46}$ The answer to this question requires that those returns be classified under the public financial support tests. It seems obvious that they will not be considered gifts, grants, or contributions since they will be receivable by the CDC pursuant to an obligation of some sort. Rather, the returns will be considered investment income.

The returns from the CDC's businesses, whether operated as subsidiaries or as divisions of the CDC itself, might be considered gross receipts, and thus it would meet the section 509(a)(2) test which permits the inclusion of gross receipts (within certain limits) in calculation of public support. ${ }^{47}$ This possibility, however, confronts several difficulties. First, and principally, only those gross receipts which are derived from "related" trades and businesses are includable in public support. Relatedness, in turn, is defined by reference to the Code provisions which tax income from unrelated trades or businesses. ${ }^{48}$ In order to satisfy the Service that such relatedness exists, the CDC must be able to demonstrate a relationship between the business and the CDC's purpose other than merely the use of the receipts for exempt purposes. In the words of the Regulations, there must be a "substantial" or "causal" relationship between the business operations and the exempt purposes for which the CDC was formed. ${ }^{49}$

Since only income from unrelated trades or businesses is taxable, the CDC's related gross receipts would not be subject to taxation. Hence, the practical

${ }^{\circ}$ This potential redetermination of the CDC's status will probably take place gradually over a number of years, in part simply because of the time it takes to establish successful businesses, and in part because both support tests determine the percentage of public support by taking the aggregate amounts of public and total support over specified preceding time periods.

\$7 This statement presupposes that the corporate form in which the operations are carried out (whether as subsidiaries or as divisions) should not be relevant to a classification of returns as investment income or as gross receipts; rather, they should be uniformly treated as gross receipts if they result from activities carried out to further the exempt purposes of the CDC. By this line of reasoning, returns should be considered investment income only if they are derived from investments which are designed solely as portfolio investments for the maintenance and growth of an organization's endowment.

${ }^{48}$ INT. REv. CODE OF I954 $\$ \$ 5 \mathrm{II-I} 4$.

10 Treas. Reg. $\$$ I.513-I(d) (I967). 
obstacle for the CDC to overcome will be the Service's fear that if it agrees that the returns from a CDC's businesses are "related" in determining whether the CDC is a public charity or a private foundation it must also agree that they are "related" in applying the unrelated business income provisions. In seeking to classify its gross receipts as related, therefore, the CDC must keep in mind that the Service may be viewing consequences other than the determination of public charity status. ${ }^{50}$

Even if gross receipts are "related," a second difficulty remains. Gross receipts may be included in public support only in amounts from any one source in a taxable year not in excess of $\$ 5,000$ or one per cent, whichever is greater. The importance of this restriction will probably vary according to the type of business producing the gross receipts. In a retail operation, such as a grocery store or a service station, it seems unlikely that one person would account for $\$ 5,000$ or one per cent of the operation's business. A manufacturing concern with only a few customers, however, might be much more adversely affected.

Lastly, it must be remembered that gross receipts, even though "related" and within the proper limits, must also be derived from proper sources, namely other public charities, governmental units, and other than disqualified persons. One type of "disqualified person" is a substantial contributor-one who during the taxable year has contributed an amount to the CDC in excess of the greater of $\$ 5,000$ or two per cent of the CDC's total contributions. ${ }^{51}$ This limitation might cause difficulty if a customer of the $\mathrm{CDC}$ were also contributing goods, services, or assistance to it free or at less than cost, as in the situation in which a well-established company assists in the formation and operation of a minority firm and is also a customer of it. At the point at which the customer would become a substantial contributor, gross receipts derived from it could not be included in support, even if otherwise qualified, because the customer would be tainted as a "disqualified person."

Assuming that a CDC formerly able to meet the public financial support tests can no longer do so, it may still continue to qualify as a public charity under the facts and circumstances test. Under that test, the CDC need only become concerned when its public support will likely fall below ten per cent of its total support. The CDC should be forewarned of this possibility well in advance of its occurrence since a four-year period is used to determine whether it normally meets the test and since the profitability of its businesses will probably build up slowly over an extended length of time.

If the CDC has so developed that it is no longer able to meet even the facts and circumstances test because of the amount of its own investment returns, it is unlikely that a section $501(c)(3)$ exemption would be of any particular value to it.

\footnotetext{
${ }^{50}$ Similar problems may arise in a CDC's attempt to classify an investment as "program-related." See n.87 infra.

${ }^{81}$ INT. REv. CODE of $1954 \$ \$ 4946$ (a) (I) (A), 507(d) (2). For CDC's in existence prior to October 9, I969, substantial contributors are those who before that date contributed the appropriate amounts. INT. REv. CODE OF $x 954 \S 507$ (d)(2)(B)(ii) and (iv).
} 
Presently, the exemption is worth seeking primarily because a CDC may more easily attract outside funds. Once a CDC becomes self-sustaining, the exemption's attractiveness diminishes considerably. Its principal value then may only be the possibility that the CDC could pull out its "profits" tax-free by successfully classifying them as related gross receipts. Rather than risk subjecting itself to private foundation status, the CDC might be well advised to relinquish its exemption, and merely become a nonprofit corporation under state law subject to taxation at normal corporate rates. If the CDC decides to do so, however, it should act before it is classified as a private foundation, since it will almost certainly be unable to terminate its private foundation status in a manner satisfactory to it. $^{\mathbf{5}}$

\section{II}

\section{Private Foundation Taxes Affecting CDC's}

A CDC which cannot qualify as a public charity under any of the three tests already discussed will be considered a private foundation. The purpose of this part of the article is to set forth those consequences emanating from private foundation designation. These consequences are, briefly, more detailed reporting requirements and the possible imposition of six operating taxes: $:^{53}(\mathrm{I})$ an excise tax on investment income; and taxes on (2) self-dealing, (3) failure to distribute income, (4) excess business holdings, (5) investments which jeopardize charitable purpose, and (6) taxable expenditures. With the exception of the excise tax on investment income, ${ }^{54}$ a general pattern can thus be seen in these levies: certain foundation activities which had led to abuse of the section 501 (c) (3) exemption in the past are discouraged through the sanction of graduated taxation. First, initial taxes are imposed on the discouraged activities, followed by much larger additional taxes if the consequences of these activities are not corrected after a specified period of time. Secondly, in the case of three of the taxes ${ }^{55}$ both initial and additional taxes are also imposed on individuals, referred to as "foundation managers" by the Act, who either make up the management of the foundation or who are responsible for the particular actions which have led to the imposition of the taxes. Initial taxes are only imposed on a foundation manager, however, if his participation is "knowing"; even then he is excused if his participation is "not willful and is due to reasonable cause." $"$ Thirdly, self-dealers and foundation managers are subject to joint and

\footnotetext{
${ }^{82}$ See note 138 infra.

${ }^{83}$ The taxes are set forth in INT. REv. CODE of I954 $\$$ 4940-46. The reporting requirements and related provisions are found in INT. REv. CoDE of $1954 \$ \$ 6033-34,6056,6 \mathrm{IO}_{4}(\mathrm{~d}), 6652$ (d), 6685 and 7207. See generally Eliasburg, $501(c)(3)$-The Private Foundation: New Procedural Requirements and Noncompliance Penalties, 45 J. STATE B. CaIIf. 860, 870-7I (I970); Lehrfeld, Private Foundations and Tax Reform: Accounting and Administrative Problems, I TAx ADVISER 4I8 (1970).

on The tax on investment income was viewed by Congress as a user or audit fee in order to pay for the costs of supervising the activities of private foundations, not as a means of discouraging certain foundation activities. SENATE REPORT, supra note 15 , at 27.

${ }^{58}$ The three are those levied on self-dealing, jeopardizing charitable purpose, and taxable expenditures.

to This language is found in all three sections. The purpose of the knowledge requirement is pur-
} 
several liability for all taxes imposed upon them, although the latter's liability is limited to either $\$ 5,000$ or $\$ 10,000$ depending on the tax involved. Lastly, only after specified correction periods have ended can additional taxes be imposed.

Following is a treatment of each of these taxes, grouped for convenience into those taxes which may affect CDC's directly (the remainder of part II), and those which may do so only indirectly through policies and practices which may be adopted by other private foundations (part III). The two taxes of greatest potential importance to CDC's-those on excess business holdings and self-dealing-are immediately discussed.

\section{A. The Tax on Excess Business Holdings}

One congressional concern transformed into law involves the substantial extent to which some exempt organizations had been engaging in conventional commercial activities. Prior law had proven ineffective because it was difficult to establish a definite point at which the business operations of the exempt organization had become so substantial that its exemption should be revoked, a step rarely taken, moreover, because of its severity. ${ }^{57}$ Section 4943 attempts to remedy these defects by providing for graduated taxation of business holdings over specified percentage limits. The section's practical effect is to force divestiture of the excess holdings. ${ }^{58}$

A private foundation is permitted to hold up to twenty per cent of the voting stock of a corporation, less the percentage of the voting stock owned by all "disqualified persons." ${ }^{20}$ Where all disqualified persons together do not own more than twenty per cent of the voting stock, then the private foundation may hold as much nonvoting stock as it wishes. Where a third party exercises effective control of the corporation, the twenty per cent figure is increased to thirty-five per cent. ${ }^{00}$ It is crucial to determine whether a CDC would be restricted to the percentage holding of this section since a CDC may in many situations wish to take equity positions larger than those permitted by the section. ${ }^{61}$

portedly to establish the proof standard of clear and convincing evidence. CoNp. REP. No. 782, 9rst Cong., Ist Sess. 280 (I969) [hereinafter cited as Conference Report]; Senaté Report 32. Additional taxes are imposed only where a manager refuses to agree to the correction of the action which led to the initial tax. Imposition of this tax should be rare. Senate Report 33.

${ }^{67}$ SeNATE REPORT 38.

${ }^{58}$ INT. REv. CODE OF I954 $\$ 4943$. The initial tax is $5 \%$ on the value of the private foundation's excess business holdings in a business enterprise. INT. Rev. CODE of I954 $\$ 4943$ (a). The additional tax is $200 \%$. INT. REv. CODE OF $1954 \$ 4943$ (b).

${ }^{50}$ INT. Rev. CODE of $1954 \$ 4943$ (c)(2)(A). The term disqualified person is defined in INT. REV. CODE of $1954 \$ 4946$ and is with two exceptions identical to the term as used in the provisions taxing self-dealings discussed in text accompanying notes $76-9 \mathrm{I}$ infra.

${ }^{00}$ INT. REV. CODE of I954 $\$ 4943$ (c)(2)(B). Similar treatment is provided for business enterprises which are not corporations, except in the case of proprietorships, in which no holdings are permitted. Id. $\S 4943$ (c) (3). A major portion of this section sets forth complex methods governing the divestiture of present excess business holdings of private foundations. Id. $\$ 4943$ (c) (4). Since most of the CDC't did not possess such holdings on the cut-off date, May 26, I969, these provisions will not be discussed.

${ }^{61}$ An example would be a joint venture with a non-minority firm in which the CDC wished voting control of the venture either initially or through buy-out provisions over a period of years. Another example, perhaps even more typical, involves a $\mathrm{CDC}$ wishing to run a retail or service operation, such 
It seems highly likely that most, and perhaps all, of a CDC's commercial activities should be unaffected by section 4943's taxes since they will be classified as "programrelated investments," investments which were expressly excluded from the section's coverage in the Senate Report. In addition to the favorable language contained in the Senate Report, the Service has recently issued proposed Regulations further elucidating program-related investments; these Regulations appear to include as program-related virtually any investment contemplated by a CDC so long as the $\mathrm{CDC}$ is able to demonstrate a connection between the investment and the economic well-being or improvement of the area which it serves. ${ }^{62}$

The language used in the discussion of section 4943 in the Senate Report seems clearly designed to exclude some typical CDC business activities from the application of the excess business holdings taxes:

Business holdings do not include "program-related investments" (such as investments in small businesses in central cities or in corporations to assist in neighborhood renovation) which are part of the foundation's charitable program, where the making of a profit for the foundation is not one of the significant purposes for holding these investments. ${ }^{63}$

The term program-related investments is discussed further in the Senate Report's explanation of section 4944 which also excludes program-related investments from the imposition of taxes on investments which jeopardize the charitable purpose of a private foundation. ${ }^{64}$ That explanation sets forth further examples of programrelated investments:

[A] program-related investment-such as low-interest or interest-free loans to needy students, high risk investments in low-income housing, and loans to small businesses where commercial sources are unavailable-is not to be considered as an investment which might jeopardize the foundation's carrying out of its exempt purposes (since such an investment is classified as a charitable expenditure). To qualify as a program-related investment, the investment must be primarily for charitable purposes and not have as one of its significant purposes that of deriving a profit for the foundation. ${ }^{65}$

as a grocery store or a day care center or planning to control the enterprise initially, divesting its ownership only after the enterprise had become established.

${ }^{82}$ Proposed Treas. Reg. $\S 53.4944-3,36$ Fed. Reg. I2027 (I97I). Program-related investments are also referred to in section 4944 as an exception to that section's prohibition against investments which jeopardize a foundation's exempt purposes. The proposed Regulations which are referred to in the text and which are immediately discussed in some detail are those issued under section 4944, not section 4943. It is thus possible that when Regulations are proposed under section 4943 the treatment of program-related investments there will be different from their treatment in the proposed section 4944 Regulations. Although this eventuality should be kept in mind, the likelihood of its occurrence seems remote in that the Senate Report gives no indication that program-related investments should be treated differently under the two sections. The more likely possibility is, as in a few other instances, that the section 4943 Regulations will merely incorporate the section 4944 Regulations by reference. See, e.g., Proposed Treas. Reg. $\$ 53.4942$ (a)-2(c)(I) (ii) (g), 36 Fed. Reg. II037 (x97I).

${ }^{03}$ Senate Report $4 \mathrm{I}$. Only excess business holdings are taxed under section 4943. The exclusion of program-related investments from such holdings thus excludes them from the section's taxes.

OL INT. REV. CODE OF $1954 \$ 4944$ (c).

os Senate Report 46. 
Program-related investments thus appear to be those made primarily for charitable purposes and not, at least significantly, for making a profit as illustrated by the examples set forth. One question immediately posed is the meaning of "charitable purposes" in the context of program-related investments. In attempting to answer it, it is instructive to examine the meaning of charitable as it is used generally in section $50 x(c)(3)$, and then to apply that meaning to the examples of program-related investments found in the Senate Report.

The definition of charitable found in the Regulations is extremely (and intentionally) broad, partly as a result of judicial usage of the term incorporated by reference and partly as a result of sweeping language found in the Regulations themselves:

The term "charitable" is used in section $501(c)(3)$ in its generally accepted legal sense and is, therefore, not to be construed as limited by the separate enumeration in section 501 (c) (3) of other tax-exempt purposes which may fall within the broad outlines of "charity" as developed by judicial decisions. Such term includes: Relief of the poor and distressed or of the underprivileged; . . . lessening of the burdens of Government; and promotion of social welfare by organizations designed to accomplish any of the above purposes, or (i) to lessen neighborhood tensions; (ii) to eliminate prejudice and discrimination .... or (iv) to combat community deterioration . . . .6

Given the typical membership and purposes of an urban or rural CDC, it is not difficult to put their operations within one, or even all, of these general statements of charitable purpose.

Program-related investments, then, appear to be those which serve the broadlydrawn statements of charitable purpose in ways similar to those set forth in the Senate Report examples. Those examples, in turn, are ( $\mathrm{I}$ ) investments in small businesses in central cities, (2) investments in corporations to assist neighborhood renovation, (3) low-interest or interest-free loans to needy students, (4) high-risk investments in low-income housing, and (5) loans to small businesses where commercial sources of funds are unavailable.

These examples imply that a proper charitable purpose can be evidenced in either of two ways: by the nature or location of the recipient itself, or by the terms on which the funds are provided to the recipient. In other words, the recipient must in some way be deserving, and the funds must be provided on favorable terms. The justification for the first requirement seems clear-the benefit of charitable activities must redound to those in need, as in example (4) (potential residents in low-income housing) or example (3) (impoverished students). The benefit, however, apparently need not be direct. It could be to a business located in, and perhaps serving, an area where the recipients live, as in example ( $\mathrm{r}$ ) (small businesses in central cities). If it is thus correct to say that a benefit, directly or indirectly, must result to recipients who are proper objects of charitable largesse, then the purposes and operations of

\footnotetext{
${ }^{66}$ Treas. Reg. $\$$ I.50I(c)(3)-x(d)(2) (1959).
} 
a typical CDC will face little difficulty in meeting this requirement. CDC's are located in poor areas, either urban or rural. In most cases their members are black, Mexican-American, or another minority which is and has been subject to discrimination, and with few exceptions whose members have not had equal opportunity to engage in business and professional activities.

The other requirement-that the terms on which the funds are provided must be favorable-appears to restate the Senate's concern that "the making of a profit ... is not one of the significant purposes for holding these investments."67 "The consequence of this requirement will be that some evidence should be available to distinguish the "charitable" business activities of a private foundation from its other commercial operations that make profits which, as the result of operations unrelated to the foundation's charitable activities, are taxable at regular corporate rates. ${ }^{68}$ Terms favorable to proper recipients also provide evidence that it is indeed their interests that lie at the center of the foundation's actions. This evidence reinforces the conclusion drawn from the nature or location of the recipient that the actions were charitably inspired.

The favorability of the terms may be demonstrated in a number of ways. Interest rates may be lower than market, or no interest at all may be charged [example (3)]; funds may be provided where, otherwise, no funds whatsoever would be available [example (5)]; and the investment may involve a high risk [example (4)]. In some cases it appears that the recipient itself (or its location) is sufficient evidence of either the terms' favorability or the propriety of the investment-funds may be invested in a small business location in a central city area on "commercial" terms [example (I)]. Also, investments may be made in corporations to assist in neighborhood renovation [example (2)]. These examples, by not expressly requiring the extension of terms more favorable than those commercially available, support the conclusion that in some cases the recipients themselves will demonstrate the charitable nature of the transaction and that the terms and purposes of the particular transaction may be the same as those which could be found in the business world between two arm's-length parties.

The proposed Regulations recently issued by the Service appear to support fully this analysis of the Senate's intent in creating an exception for program-related investments. In a series of eight examples the Regulations attempt to illustrate the kinds of investments which will be considered program-related in that their primary purpose will be to accomplish the charitable or other exempt purposes of the organization. ${ }^{6 \theta}$ These examples demonstrate their program-related nature principally

\footnotetext{
${ }^{\circ 7}$ SENATE REPORT 4x.

${ }^{08}$ INT. REv. CODE OF $1954 \$ 5$ II (unrelated business income tax).

${ }^{00}$ Proposed Treas. Reg. $\$ 53.4944-3$ (a)(I), 36 Fed. Reg. 12027 (I97I). In addition to the eight examples, the proposed Regulations also include as program-related investments the five kinds of program-related investments set forth in the discussions of sections 4943 and 4944 in the Senate Report. The fact that the Regulations do refer to investments mentioned by the Senate under both sections appears to indicate that the Service recognizes the identity of program-related investments under both sections,
} 
through the benefit which they will directly or ultimately confer on members of an economically-disadvantaged minority group, and tend to downplay the requirement (as was implicit in the Senate Report) that investments be made on favorable terms in order to demonstrate the absence of a profit motive. Thus, in those examples in which favorable terms are found it is apparent that without such terms it might be difficult to determine whether the investment was commercial or charitable. ${ }^{70}$

- It cannot be ascertained in some of the examples whether all of the factors are essential since several are mentioned. It is clear, however, that a CDC may either assist a business controlled by others or one which it owns itself. ${ }^{71}$ Moreover, if the business assisted is small, minority-owned, located in a poor area, and unable to obtain funds from conventional sources, then the CDC may make assistance available to it on commercial terms, so long as the CDC disclaims any intent to make a profit and can point to a colorable justification for the assistance being extended. ${ }^{2}$

In addition to investments which encourage minority ownership, those investments which increase employment opportunities to minority people from a poor area are classified as program-related in the proposed Regulations. Moreover, even though the business is not owned by low-income or minority people and not located in the low-income area itself, the foundation may apparently charge commercial interest rates if it appears that the business will be sufficiently profitable to meet the payments. ${ }^{73}$ In fact, in only one example is the foundation prevented from charging the commercial rate-when it induces a "financially secure" business enterprise, "the stock of which is listed and traded on a national exchange," to establish a plant in a deteriorated urban area. ${ }^{74}$ Even in this instance, moreover, it may very well be that a commercial interest rate would have been permissible because the below-market rate was demanded by the business enterprise itself in order to compensate for the other high risks involved. Since the loan was made by the foundation "to enhance the economic development of the area by providing employment oppor-

and, that when it issues Regulations under section 4943 , it will pattern its discussion of program-related investments there on its exposition of them under section 4944 .

${ }^{70}$ Proposed Treas. Reg. $\$ 53.4944-3$ (c), examples (4) and (5), 36 Fed. Reg. 12028 (197 1 ).

${ }^{71}$ Proposed Treas. Reg. $\$ 53.4944-3(c)$, examples (6) and (8), 36 Fed. Reg. 12028 (x971).

${ }^{72}$ Proposed Treas. Reg. $\$ 53.4944-3(c)$, examples ( $x$ ), (3), and (6), 36 Fed. Reg. 12028 (1971). In example ( $(2)$, a loan is provided "at or below the market rate for commercial loans of comparable risk," because the "terms of the loans are primarily intended to demonstrate to the financial community the economic viability of such [minority] enterprises." Moreover, the foundation's "primary purpose for making such loans is to encourage the economic development of such minority groups." In example (3), the ultimate financial benefit which might redound to the foundation is even greater since there the foundation purchases shares of the common stock of the business in order to convince conventional lending sources to participate, those sources being unwilling to provide funds "unless [the business] increases the amount of its equity capital." By purchasing the stock, the foundation is making a programrelated investment "even though [it] may realize a profit if [the business] is successful and the common stock appreciates in value." In example (6), the foundation makes a loan to a business owned by it on the same terms as those demanded by conventional sources ("whose primary purpose for making the loan is financial"). The loan is nevertheless considered to be a program-rclated investment because it. triggered the loan from the other sources.

. ${ }^{73}$ Proposed Treas. Reg. $\$ 53.4944-3$ (c), example (4), 36 Fed. Reg. 12028 (197I).

${ }^{74}$ Proposed Treas. Reg. $\$ 53.4944-3$ (c), example ( 5 ), 36 Fed. Reg. 12028 (197). 
tunities for low-income employees at the new plant," presumably the same would hold true if the foundation were to make funds available to a business enterprise which, for whatever reasons, was itself willing to assume the higher risks involved. Thus, perhaps the mere provision of capital by a foundation would alone be sufficient inducement to a business enterprise, and, so long as the foundation could demonstrate a charitable purpose, would qualify the investment as program-related. ${ }^{75}$

Under the proposed regulations, a CDC should be able to demonstrate that its investments are program-related in all but the most exceptional instances. Even investments in businesses located outside the CDC's usual area of operations might be justified as program-related if the enterprises were within commuting distance, since they could be said to provide employment opportunities. In general, it appears that only those investments of an entirely passive nature will be indefensible as program-related. Since it is difficult to imagine CDC's holding more than the twenty per cent or thirty-five per cent investment permitted by section 4943 in such enterprises, it is likely that the impact of section 4943 on them will be negligible if the proposed Regulations are adopted as final in substantially their present form.

\section{B. The Taxes on Self-Dealing}

Prior to the Act, section 503 permitted dealings between some types of exempt organizations and persons related to them if the transactions appeared to be the result of arm's-length negotiations. ${ }^{76}$ Difficulties were encountered, however, in determining whether particular dealings met this standard. Moreover, even some that clearly did meet the standard were felt by Congress to be objectionable. ${ }^{77}$ Also, the only sanction for engaging in prohibited dealings was removal of the exemption, an extreme step rarely and reluctantly taken. The Act attempts to remedy these deficiencies of prior law by imposing a series of graduated taxes on most dealings between private foundations and disqualified persons, whether at arm's-length or not. ${ }^{78}$

There are, in general, three categories of disqualified persons: (I) substantial contributors to the foundation, (2) foundation managers, and (3) certain government

\footnotetext{
75 This statement also seems to be supported by more general language found elsewhere in the Regulations which states that "the fact that an investment produces significant income or capital appreciation shall not, in the absence of other factors, be conclusive evidence of a significant purpose involving the production of income or the appreciation of property [which would disqualify the investment as programrelated]." Proposed Treas. Reg. \$53.4944-3(a) (2)(iii), 36 Fed. Reg. 12027 (I97I).

${ }^{70}$ Section 503 applied only to those organizations could not meet the publicly-supported tests in the Regulations. Section 503 no longer applies to "private foundations," as sections $494 \mathrm{I}$ and 4946 were designated to supplant it. Senate Report, supra note 15 , at 29.

${ }^{77}$ An example of the latter concern is a loan made by the foundation to a donor on commercial terms but in a tight market where the donor might otherwise have had greater difficulty in obtaining any funds at all. This and other examples are cited in SENate Report 28-29.

${ }^{78}$ INT. REv. CODE of $1954 \$ 494 \mathrm{I}$. The taxes imposed are to be paid by the disqualified persons and, in some cases, by those responsible for the foundation's part in the dealing, but not by the foundation itself. INT. Rev. CODE of I954 \$494I(a) and (b). See also Proposed Treas. Reg. \$53.494I(a)-I (a) (I), 36 Fed. Reg. I0968 (197I). The Service has recently issued proposed Regulations on disqualified persons. Proposed Treas. Reg. 53.4946-I, 36 Fed. Reg. 6430 (I97I).
} 
officials. ${ }^{79}$ A substantial contributor is defined as any person (including a corporation or other entity) which gives the foundation more than $\$ 5,000$ or two per cent of the foundation's total contributions during any taxable year, whichever is greater ${ }^{80}$ The term foundation manager includes any director, officer, or trustee of a foundation (or one performing similar functions, regardless of his title), and any employee having authority or responsibility for the act which led to the imposition of the tax. The broad sweep of this definition is curtailed under other sections setting forth specific taxes which require that the foundation manager must know that his act is one of self-dealing. Even where this knowledge exists, the provisions excuse him if his participation is "not willful and is due to reasonable cause."181 Thus, the treatment of foundation managers and other disqualified persons is substantially different, as the latter are taxed regardless of their state of mind and the responsibility for the transaction at issue.

In addition, persons or organizations may be considered disqualified persons because of their relationship to a foundation manager or a substantial contributor. Entities in which a disqualified person has specified interests will also be considered disqualified as will owners of more than specified percentage interests in a dis. qualified entity. In addition, particular family relationships also expand the coverage of those considered disqualified. All of these measures are designed to prevent one person or entity from accomplishing indirectly what it cannot do directly. ${ }^{82}$ The last general category of disqualified persons, government officials, includes those in public office who are likely to be politically powerful themselves, who are in relatively high-level policy-making positions, or who are potentially influential because of their close relationship to either of the former..$^{83}$

The Code specifies in section 494I the types of dealings between disqualified persons (as discussed above) and private foundations which are either precluded

\footnotetext{
${ }^{70}$ INr. Rev. CoDe of $1954 \$ 4946$ (a)(I)(A), (B), and (I); Proposal Treas. Reg. $\$ 53.4946-\mathrm{I}$ (a)(1)(i) and (ii), and (c), 36 Fed. Reg. 6430-3I (I97I).

${ }^{80}$ INT. REv. CODE OF $1954 \$ 507$ (d)(2)(A). If the foundation was in existence before October 9 , r 969 , those who are to be considered substantial contributors are determined by first assuming that all contributions or bequests received on or before October 9 were received on that day and then computing whether the particular contributor gave in excess of the applicable limit ( $\$ 5000$ or $2 \%$ ). Once one qualifies as a substantial contributor, moreover, he remains a substantial contributor. INT. REv. CODE OF 1954 $\$ 507$ (d)(2)(B) (ii) and (iv); Proposed Treas. Reg. $\$ 1.507-6(b), 36$ Fed. Reg. 6429 (x97x).

${ }^{81}$ INT. REv. CODE of I954 $\$ 494 \mathrm{I}$ (a)(2) (self-dealing), $\$ 4944$ (a) (2) (jeopardizing charitable purpose), and $\S 4945$ (a)(2) (taxable expenditures). It should be noted, however, that the limitations on the liability apply only when the individual is acting in his capacity as a foundation manager. When, in contrast, he is dealing on his own behalf with the foundation (as, for example, where a foundation director is selling a piece of land owned by him to the foundation), he would be liable for the tax as a disqualified person. See INT. REv. CODE of I954 \$494I(a) (I). Compare Proposed Treas. Reg. \$53.494I (a) $-\bar{x}(\mathrm{a})$ (I) with Proposed Treas. Reg. $\$ 53.494 \mathrm{I}$ (a)-I(b), 36 Fed. Reg. I0968-69 (I97I).

${ }^{2}$ See INT. Rev. CODE of $1954 \$ 4946$ (a) (I)(C)-(G); Proposed Treas. Reg. $\$ 53.4946-$ I (a)(I)(iii) to (vii), and (d), and (e), 36 Fed. Reg. $6430-32$ (x971).

${ }^{88}$ INT. Rev. CoDE of I954 $\$ 4946$ (a) (I)(I) and (c); Proposed Treas. Reg. $\$ 53.4946-I$ (c) and (g), 36 Fed. Reg. 6432 (I97I). In its definition of a government official, the Service distinguishes "public office" from public employment. Proposed Treas. Reg. $\$ 53.4946-\mathrm{I}(\mathrm{g})(2), 36$ Fed. Reg. 6432 (197r).
} 
altogether or substantially restricted. In general, it can be stated that a disqualified person may not enter into any transaction with a private foundation if he will benefit from it in any way. There are two exceptions: he may be a beneficiary of the foundation's programs on the same footing with any member of the general public, and he may be paid reasonable compensation for personal services which are reasonable and necessary to carry out the foundation's exempt purposes. ${ }^{84}$ Thus, all real or personal property transactions with a foundation are taxable, including any leasing arrangements, and even gifts of the property if it has been mortgaged in a proscribed manner. Similarly, all monetary transactions are subject to taxation except for no-interest loans which are made by the disqualified person to the foundation and which are to be used for exempt purposes. ${ }^{85}$ In addition, no goods, services, or facilities may be furnished by a disqualified person to the foundation, except that he may do so at no cost if what he furnishes is used for exempt purposes, or if certain pre-established business relationships are involved. ${ }^{86}$

These prohibitions may be of importance to a CDC in several ways. Perhaps the most obvious is business dealings between the CDC and other corporations (or individuals). In some cases, one or a number of corporations may assist a particular business operation of a CDC by providing equity capital, loan funds, technical and business advice, or guaranteed markets for the products of the operation. If a corporation has contributed an amount sufficient to render it a substantial contributor, it would arguably be foreclosed from any further dealings with the CDC, except by gift. Thus, contracts for any goods or services might be barred under the prohibition upon the furnishing of these by or to a private foundation. ${ }^{87}$

\footnotetext{
${ }^{84}$ Int. Rev. CoDE of I954 $\$ 494 \mathrm{I}$ (d); Proposed Treas. Reg. $\$ 53.494$ I (d)-I, 36 Fed. Reg. I0970-7I (I97I). The exceptions are stated in $\$ 494 \mathrm{I}(\mathrm{d})(2)(\mathrm{D})$ and (E), and in recently proposed Regulations. Proposed Treas. Reg. $\$ 53.494 I$ (d)-3(b) and (c), 36 Fed. Reg. ro973 (197I).

${ }^{85}$ INT. Rev. CoDe of I954 $\$ 494$ I (d)(I)(B) and (2)(B); Proposed Treas. Reg. $\$ 53.494 \mathrm{I}$ (d)-2(c), $3^{6}$ Fed. Reg. 1097I (I97I). The Regulations appear to omit the requirement that the loan proceeds be used for exempt purposes.

No loan, regardless of its terms, is permitted from the foundation to the disqualified person. INT. REv. CODE OF I954 $\$ 494 \mathrm{I}$ (d)(I)(B).

${ }^{80}$ INT. Rev. CoDe of I954 $\$ 494 \mathrm{I}$ (d)(I)(C) and (2)(C); Proposed Treas. Reg. $\$ 53.494 \mathrm{I}$ (d)-r(b) and 2 (d) (3), 36 Fed. Reg. ro97o, ro972 (197I).

87 There is one possible exception to this statement. Since a foundation is permitted to furnish goods or services to a disqualified person on the same basis as it does to the "general public" the CDC might argue that its furnishing of goods or services to the disqualified corporation is permissible by defining general public as the class of buyers for the goods or services. The definition of general public in the proposed Regulations is basically conclusory, and thus not of much assistance: "the term 'general public' shall include those persons who, because of the particular nature of the activities of the private foundation, would be reasonably expected to utilize such goods, services, or facilities." Proposed Treas. Reg. $\$ 53.494 \mathrm{I}$ (d)-3(b) (2), 36 Fed. Reg. rog73 (r97I). Although this definition certainly leaves room for a general public which is a narrow class of people or organizations, the two textual examples provided as illustrations suggest a broader interpretation. Id.

A second difficulty confronting a CDC in attempting to use the general public exception is that the proposed Regulations require that the goods or services be "functionally related," as that term is defined in section $4942(j)(5)$. In order to satisfy this requirement, the CDC would have to demonstrate that the goods or services furnished were "related" to its exempt purposes. Unfortunately the concept of "relatedness" set forth in section $4942(j)(5)$ and found elsewhere in other sections of the Code (particularly those dealing with "related" and "unrelated" business income) have not been dovetailed as yet
} 
The tax on self-dealing would seemingly also operate in the situation in which the corporation provides goods, equipment, land, money, or services to the CDC, not as a gift, but on terms more favorable than those offered to others. Examples include a sale of land to the CDC at less than its original cost or a sale of equipment at a price equal to its adjusted basis. Both seem precluded by the taxation of any "sale . . . of property between a private foundation and a disqualified person." 88 Similar problems might arise if a foundation had made a grant to a CDC and later considered making a loan or providing technical assistance at a reduced cost. ${ }^{80}$

Although it appears that in some instances the corporation or foundation could not deal with the CDC directly, it must be asked whether a transaction with an organization related to the CDC would be permitted. For example, a foundation which had made a grant to the CDC (which caused it to become a substantial contributor) might subsequently enter into a loan agreement with a subsidiary of the CDC. It is unlikely that this would be permitted, as self-dealing is defined to preclude the specified activities whether they are "direct or indirect."

It is of no consequence that an action is undertaken to further exempt purposes. The exceptions to the prohibitions against making loans and furnishing goods, services, or facilities are based both on their being provided cost-free and on their being used for exempt purposes. Thus, a loan at a lower-than-market rate of interest, even for exempt purposes, would fail to meet the former standard. In addition, no exception at all is provided for exchanges of property.

The consequence is that a CDC must be constantly aware of the possibility that a benefactor will become a substantial contributor and that the CDC may thus be unable to deal with it, even in transactions which seemingly complement those objectives which led to the initial contribution. It cannot be said that Congress was unaware of problems such as these. The Senate Report notes:

It has been suggested that many of those with whom a foundation [the CDC] "naturally" deals are, or may be disqualified persons. However, the difficulties that prompted this legislation in many cases arise because foundations "naturally" deal with their donors' businesses.

If a substantial donor owns an office building, the foundation should look elsewhere for its office space..$^{90}$

with the program-related investments exceptions of sections 4943 and 4944 . It is thus presently uncertain whether a CDC may demonstrate an investment to be "functionally related" merely by showing that it is program-related, or whether additional, or even completely separate, considerations are involved.

${ }^{88}$ INT. REV. CODE OF I954 $\$ 4945$ (d) (I)(A).

${ }^{89}$ The Regulations do provide an exception to the prohibitions on self-dealing for certain business transactions, which may in a few instances alleviate the rigor of the self-dealing provisions on CDC's. The exception's standards are fairly stringent, however, requiring that the business relationship exist before the transaction takes place, that the terms of the transaction be as favorable to the CDC as those secured in arm's-length negotiations, and that "severe economic bardship" would be caused the CDC if it were forced to engage in the transaction with another party. Proposed Treas. Reg. $\$ 53.494 x$ (d)$I(b)(I), 36$ Fed. Reg. I0970 (I97I).

${ }^{80}$ Senate Report 30. 
The possibility that a CDC might be unable to obtain assistance which would have been provided but for the taxes on self-dealing demonstrates that a CDC should not be considered a private foundation in the first place. The evils against which Congress was directing these provisions were those arising from situations involving a much closer relationship between the donor and the private foundation, as where the donor, in fact, was able to control or manipulate the foundation to his advantage. ${ }^{21}$ This is not the case with the typical CDC. It seems, rather, that the $\mathrm{CDC}$ is unintentionally being caught up in the consequences of a literal reading of provisions enacted for other, albeit laudable, aims.

\section{The Taxes on Investments which Jeopardize Charitable Purpose}

It is virtually certain that the usual activities of CDC's will not be subject to taxation under section 4944 which proscribes "investments which jeopardize charitable purpose." Although the statutory language itself does not define the content of such investments, the Senate Report suggests that the section is intended to affect highrisk, high-yield investments which reveal that the private foundation is engaged in highly speculative financial dealings. For example, the Report disapproves the past practices of some foundations of investing their assets in "warrants, commodity futures, and options, or ... purchases on margin of [investments which] otherwise risk the corpus of the foundation." ${ }^{\text {"2 }}$ Section 4944 thus appears designed to prevent such investments, which are clearly unrelated to the exempt purposes of the foundation. ${ }^{\text {93 }}$

It is true that investments of the type typically made by a CDC involve extreme risks. The Senate appears to have anticipated the contention that they would be taxed under section 4944, for it excluded "program-related investments" from the section's proscriptions. ${ }^{94}$ The Senate Report offers three examples of such investments: low-interest or interest-free loans to needy students, high-risk investments in low-income housing, and loans to small businesses where commercial sources of funds are unavailable.$^{95}$ It is apparent that the factor of high risk, while perhaps necessary to trigger the application of section 4944, is itself not sufficient. A finding is also necessary that the investment is unrelated to the exempt purposes of the CDC.

\footnotetext{
${ }^{01}$ Goray, Private Foundations under the Tax Reform Act of 1969, I6 WAYNE L. REv. I277, I277-8I (1970).

${ }^{03}$ SenATE Report 45.

${ }^{08}$ Prior to the Act income of a foundation could not be invested if the purpose of the foundation would consequently be jeopardized. INT. Rev. CoDE of I954 $\$ 504$ (a)(3). Section 4944 extends this prohibition to both assets and income. See INT. REv. CODE OF I954 $\$ 4944$ (a) (I) ("If a private foundation invests any amount ....") (emphasis supplied).

'INT. Rev. CODE OF I954 $\$ 4944$ (c). "Program-related investments" are discussed at length in the text accompanying notes $62-75$ supra.

${ }^{05}$ SENATE REPORT 46. The Senate examples have been adopted and expanded upon in recently proposed Regulations. Proposed Treas. Reg. $\$ 53.4944-3$, 36 Fed. Reg. I2027 (1971).
} 


\section{The Taxes on Taxable Expenditures}

Section 4945 taxes a miscellany of activities, termed "taxable expenditures," which Congress viewed as outside the scope of a private foundation's proper purposes. ${ }^{90}$ Most of the proscribed activities would not normally be carried on by a CDC, but a few might be, and the "expenditure responsibility" provisions of the section will prove important if the CDC is receiving funds from another private foundation.

Taxable expenditures are defined as amounts spent on any of the following activities: (I) lobbying and attempting to influence public opinion for the purpose of affecting legislation; (2) attempting to influence the outcome of any specific public election or to carry on voter registration drives unless the organization is a section $501(c)(3)$ organization specifically formed to carry out voter registration activities; (3) making individual travel and study grants unless such grants are awarded on an approved objective and on a nondiscriminatory basis; and (4) making grants to any organization (except section 501 (c) (3) organizations which are not private foundations) unless the grantor private foundation insures that the grant is spent solely for the purpose for which it is made, obtains complete reports from the grantee, and makes detailed reports to the Service (the "expenditure responsibility" provisions). There is, in addition, a general catch-all which taxes all expenditures "for any purpose other than [an exempt] one."

The first three categories reflect congressional concern with activities which should rarely be a part of the operations of a CDC, and need only be briefly discussed. The first two categories discourage those activities which are of a partisan political nature, such as grass roots lobbying, supporting particular candidates for public office, and contacting members of a legislature in an attempt to affect particular legislation. Excepted is nonpartisan analysis, study, or research, and the furnishing of technical information requested in writing by legislators. ${ }^{98}$

The prohibitions on some types of grants to individuals should seldom trouble a CDC. ${ }^{99}$ These restrictions do not extend to contracts for services, the arrangement

${ }^{80}$ The initial taxes on taxable expenditures are $10 \%$ and $2 \frac{1}{2} \%$ for the foundation and the foundation managers respectively. INT. REv. CoDe of $1954 \$ 4945$ (a). The additional taxes are roo\% and $50 \%$. INT. REv. CODE of I954 $\$ 4945$ (b). The Service has recently issued proposed Regulations for this section. Proposed Treas. Reg. $\$ 53.4945,36$ Fed. Reg. 5357 (I97I).

${ }^{97}$ Taxable expenditures are defined in broad terms in $\$ 4945$ (d), and then treated further in $\$ 4945$ (e)(h). The impact of the catch-all provision is difficult to gauge. It could be used by the Service to deter attempted circumventions of the other provisions, especially grants to individuals. Both committee reports mention the provision only in passing; its importance will await the Service's decision on its utility. The proposed Regulations specifically exclude unreasonable administrative expenses. Proposed Treas. Reg. $\$ 53.4945-6$, 36 Fed. Reg. 5367 (I97 I).

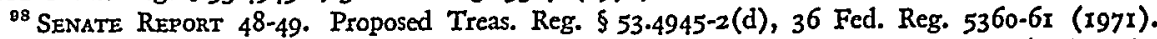

${ }^{\circ 0}$ In the recently issued proposed Regulations, however, "grant" is surprisingly defined to include loans and program-related investments. Proposed Treas. Reg. $\$ 53.4945-4(\mathrm{a})(2), 36$ Fed. Reg. 5362 $(197 \mathrm{r})$. Since there is no mention in either committee report of such an unusual definition, it is difficult to understand the Service's reasoning in adopting it. A CDC must be aware that its investment program may have to meet the criteria established in the Regulations, at least so far as its investments or loans are extended to individuals rather than to legal entities such as corporations or partnerships. 
which would usually be found in a CDC's operations. ${ }^{100}$ Problems of self-dealing rather than individual grants seem more likely to trouble a typical CDC in this respect. The provisions of section 4945 are not intended to limit those on selfdealing. ${ }^{101} \mathrm{~A}$ grant to an individual who was a disqualified person within the meaning of the self-dealing provisions would probably be precluded as "a transfer to ... a disqualified person of the income or assets of a foundation ...."102 In any event, should a CDC institute any sort of scholarship or award program, it must be certain that proper objective standards are established and maintained.

The portion of section 4945 most likely to affect CDC's is the fourth category, the "expenditure responsibility" provisions intended to ensure that grants are made and expended for exempt purposes. These provisions apply, however, only where both the grantor and the grantee are not public charities. In the case of a typical CDC, these provisions will be of most importance where the $\mathrm{CDC}$ as a private foundation is seeking funds from another private foundation. The grantor foundation will thus have to assume the burden of "expenditure responsibility" if it wishes to make the grant to the CDC. Since the effect of the provisions is thus indirect in the sense that the principal burden is on an organization other than the $C D C$, it is discussed below with those other provisions similarly affecting $\mathrm{CDC}$ operations indirectly.

\section{E. The Excise Tax Based on Investment Income}

Every private foundation is subject to a four per cent tax on its net investment income. ${ }^{103}$ In contrast with the other excise taxes potentially applicable to a private foundation's operations, this tax is designed as a source of revenue in order to cover the increased costs which the Service will incur in administering the private foundation provisions..$^{104}$ Net investment income consists of net capital gain and gross investment income less the expenses incurred in obtaining the latter. The net capital gain is determined by taking the net gain from sale or distribution of property used to generate gross investment income, plus the gain from the sale or disposition of property the use of which results in unrelated business income under section $5 \mathrm{II}$, less any net capital gain used in computing the tax under that section.

Gross investment income is defined as income from interest, dividends, rents, and royalties, excluding any such income which has already been used in computing the unrelated business income tax under section 5 II. Before passage of the Act, investment

\footnotetext{
${ }^{100}$ Senate Report 50; H.R. Rep. No. 9I-4r3, 9Ist Cong., ist Sess. 35 (x969). That a foundation might attempt to label a questionable grant a "contract for services" was recognized in the House Report, but the problem of distinguishing the two was minimized as no more difficult of solution than questions of excessive compensation. Id.

101 Senate Report 50, n.xg. Proposed Treas. Reg. $\$ 53.4945-4$ (a)(I), 36 Fed. Reg. 5362 (I97I).

${ }^{102}$ INT. REv. CODE OF I954 $\S 494 \mathrm{I}$ (d)(I)(E). This interpretation is suggested by the negative implication of the special exception in $\$ 494 \mathrm{I}$ allowing government officials (who are one type of disqualified person) to receive prizes, awards, and scholarships if made on an objective basis. INT. Rev. CODE OF I954 $\$ 494$ I(d)(2)(G)(i) and (ii). See Senate Report 32.

${ }^{103}$ INT. Rev. Code of I954 $\$ 4940$; Proposed Treas. Reg. $\$ 53.4940,36$ Fed. Reg. 5355 (I97I).

${ }^{104}$ Senate Report 27.
} 
income was not included in unrelated business income. The Act, however, in addition to enacting section 4940, expanded the definition of the unrelated business income to include a certain proportion of income from interest, annuities, royalties, and rents (but not dividends) if that income is derived from a "controlled" organization. ${ }^{105}$ The language of section 4940, in excluding investment income already included under section $5 \mathrm{rr}$, appears intended to avoid the occurrence of double taxation.

A practical consequence of the investment income tax is that tax treatment of dividends may become less favorable to nonprofit corporations. Dividends received by exempt organizations are excluded from unrelated business income. Although still excluded as such, they are now subject to the four per cent investment income tax. For-profit corporations, in contrast, may exclude eighty-five per cent of dividends received. ${ }^{106}$ The effective result is that for-profit corporations are subject to at least a 3.3 per cent and at most a 7.5 per cent tax on dividends. ${ }^{107}$

\section{III}

\section{TaXes Indirectly Affecting CDC's}

Those penalty taxes already discussed may affect a CDC's operations directly. The effect of some of the other taxes, in contrast, will be felt indirectly, if at all, because they may discourage other private foundations from dealing with CDC's by imposing taxes on dealings between one private foundation and another. The impact of these taxes will be examined on the assumption that a private foundation is considering a grant to a CDC. ${ }^{108}$ As the ensuing discussion will attempt to demonstrate, the effect of these taxes should be minimal. The possibility of their affecting CDC's in any substantial manner in the short run will be due to the cautious advice of the grantor private foundation's counsel, reflecting his uncertainty as to what the Service's position will ultimately be. Over the long run, it should become clear that the additional burden will be insignificant.

${ }^{105}$ INT. Rev. CODE OF I954 $\$ 5 \mathrm{I} 2$ (b)(I5). This amendment to the unrelated business income provisions may have important consequences to a $\mathrm{CDC}$ which controls its commercial operations through subsidiaries, as it will no longer be able to extract profits in the form of interest on loans. Prior to the Act it was desirable from a tax standpoint to capitalize the subsidiary as thinly as possible, since interest payments were deductible to the subsidiary, and not includable in the parent's income. Dividends, in comparison, enjoyed only the latter advantage. Section $5 I 2(b)$ (I5) defines "control" by reference to $\$ 368(c)$, which establishes, very roughly, a standard of $80 \%$ stock ownership. Section $5 \times 2$ (b) (15) may thus encourage a CDC to divest its holdings in its subsidiaries below the $80 \%$ mark so that the subsidiaries may take advantage of deductions for interest on loans from the parent CDC to them.

${ }^{100}$ INT. REv. CODE OF I954 $₫ 243$ (a)(I).

${ }^{102}$ The $7 \frac{1}{2} \%$ figure is based on the maximum corporate tax rate of approximately $50 \%$. An $85 \%$ exclusion leaves $15 \%$ subject to tax, half of which is $7 \frac{1}{2} \%$. The difference is even less, of course, where the corporate profits are not sufficiently large so as to be taxed at the maximum rate.

${ }^{108}$ It is possible, of course, that the CDC might be the grantor and another organization the grantce, in which case the CDC would be directly affected by the taxes to be discussed. Given the early stages of development of the business operations of most CDC's, however, the emphasis at this time seems better placed on the CDC as grantee. 


\section{A. The Taxes on Failure to Distribute Income}

Before the Act an exempt organization which made an unreasonable accumulation of income faced possible loss of its exemption. ${ }^{109}$ Problems were encountered both in attempting to gauge when unreasonable accumulations should be found to exist and in justifying a sanction as harsh as removal of the exemption. Section 4942 attempts to remove the subjective element previously inherent in a standard of unreasonable accumulation by requiring a private foundation to make qualified distributions of either its adjusted net income, ${ }^{110}$ or an amount equal to a certain percentage (termed the "minimum investment return") of the foundation's "net" assets, whichever is greater. ${ }^{111}$ The all-or-nothing approach militated by the sole sanction of removal of the exemption has also been replaced by taxes graduated in severity. ${ }^{112}$ As a consequence of these changes, exempt organizations should cease to be a haven for tax deductions from their donors while never, or rarely, expending funds for exempt purposes.

The typical CDC itself will not likely be subject to the taxes imposed by this section, as it will undoubtedly be making qualified distributions in an amount easily in excess of the amounts which it must disburse in order to meet the section's

${ }^{109}$ INr. REv. CODE of $1954 \S 504$ (a) (I). Section 4942 (taxing failure to distribute income) is intended to replace the repealed section. SENATE REPORT, supre note $I_{5}$, at 35 , n.6.

${ }^{210}$ Adjusted net income under this section is similar to adjusted gross income as defined in section 62 except for certain added income and deduction modifications. INT. REv. CoDE of I954 $\$ 4942(f)$.

211 Quite detailed proposed Regulations have recently been issued by the Service under Section 4942. Proposed Treas. Reg. $\$ 53.4942$ (a), 36 Fed. Reg. II034 (I97I). Net asset value is determined by establishing the fair market value of the foundation's assets not used for exempt purposes less certain kinds of debt (termed acquisition indebtedness) to which the assets are subject. INT. REv. CoDE of I954 $\$ 4942$ (e)(I)(A); Proposed Treas. Reg. $\$ 53.4942$ (c)-2(c), 36 Fed. Reg. II037-38 (r97I). The minimum investment return percentage applicable to organizations organized on or after May 27, I 969 is $6 \%$. Those organized before that date are subject to lesser, but increasing, minimum investment return percentages through 1974 in order to allow them sufficient time to alter their present investment policies. INT. REv. CODE of I954 $\$ 4942(\mathrm{e})(3)$ and (4); Tax Reform Act of I969 $\$$ IOI(I) (3) (A), 83 Stat. 534; Proposed Treas. Reg. $\$ 53.4942$ (a)-2(c)(3), 36 Fed. Reg. Iro38 (I97I).

The alternate requirements of the higher of adjusted gross income or the minimum investment return are designed to force a private foundation to distribute at least a certain minimum amount (the minimum investment return), and possibly more (all adjusted gross income), if its investment policies prove successful. Without congressional imposition of the floor of the minimum investment return, private foundations could have modified their investment policies so that no income was generated. The floor encourages a private foundation to attain a return on its investment at least equal to the minimum investment return, since it will otherwise be forced to deplete its corpus in order to make the distributions. To illustrate, assume that the foundation's net assets are found to be $\$ 100,000$, and that the applicable minimum investment return is $6 \%$. If in fiscal 1970 the foundation had an adjusted net. income of $\$ 9,000$, it would be required to distribute all of the $\$ 9,000$ for qualified purposes. If its adjusted net income was only $\$ 4,000$, then it would have to distribute that income for qualified purposes, and $\$ 2,000$ in addition, since the minimum investment return at $6 \%$ of $\$ 100,000$, would be $\$ 6,000$. In order to obtain the $\$ 2,000$, the foundation would presumably have to draw from its corpus, thus reducing its net assets to $\$ 98,000$. See Proposed Treasury Regulations sections 53.4942(a)-I(a) (I) and 53.4942(a)3 (d) and (e), 36 Fed. Reg. II035, Iro42-43 (I97I) for the timing, carry-forward, and carry-back provisions for undistributed amounts.

${ }^{113}$ The initial tax imposed under this section is equal to $15 \%$ of the undistributed income of the private foundation, with an additional tax equal to $100 \%$ of the amount remaining undistributed at the end of the correction period. INT. REv. CoDE of I954 $\$ 4942$ (a) and (b); Proposed Treas. Reg. $\$ 53.4942$ (a) $-1,36$ Fed. Reg. Iro35-37 (I97I). 
requirements. Qualified distributions are defiend ( $I$ ) as program-related investments, and (2) by reference to section $I 70(c)(2)(B)$ as those for "religious, charitable, scientific, literary, or educational purposes, or for the prevention of cruelty to animals ...." Qualified distributions may take a variety of forms other than a grant. Assets purchased for qualified purposes, for example, will be considered qualifying distributions. ${ }^{113}$ Loans will almost certainly qualify as well, if made for proper purposes, on the condition that repayments of principal and interest be again considered distributable income. ${ }^{114}$ Lastly, a private foundation may make a qualifying distribution by setting aside funds to be used for future exempt purposes if the foundation can satisfy the Service that the amounts will be used for a specific project and that the project will be better accomplished through the postponement of a present qualifying distribution. ${ }^{115}$ Assuming that the typical CDC has been granted a section 501 (c) (3) exemption initially to carry on activities such as making loans to appropriate businesses, guarantees of bank or other institutional financing, or equity investments in appropriate businesses or in its own concerns, there should be little doubt that it has made qualified distributions well in excess of the relatively small amounts required by section 4942 .

The only likely instance when this section will have an impact on a typical CDC is the limited case where the CDC, as a private foundation, seeks funds from another private foundation which is attempting to qualify its grants as a proper distribution under section 4942. Assuming that the distribution is for qualified purposes, ${ }^{116}$ then it can be made by the private foundation to any grantee without further concern under section 4942, unless the grantee is also a private foundation. In that case, unless the grantee is a special type of private foundation (termed an operating foundation), the grant must be either redistributed by or pass through the grantee within one year, and the grantor must obtain sufficient evidence that this

\footnotetext{
${ }^{118}$ INT. Rev. CODE of $1954 \$ 4942$ (g)(I)(B); Proposed Treas. Reg. $\$ 53.4942$ (a)-3(a)(I)(ii), 36 Fed. Reg. Iro40 (I97I).

114 See INT. Rev. CODE of I954 \$4942(f)(2)(C)(i); Proposed Treas. Reg. $\$ 53.4942$ (a)-2(d)(2)(iii), 36 Fed. Reg. 11038 (197r). The obscurity of the statutory language and the Regulations is illuminated by language in the Senate and Conference Reports, both of which state clearly that loans made by a private foundation should be treated as qualifying distributions at the time when they are made. Senate Report 36; Conference Report 282. The same principle will apply in any case where an amount once treated as a qualifying distribution is later returned or made available to the foundation. SENATE REPORT 36, n.8.

${ }^{115}$ INT. Rev. CODE of I954 $\$ 4942$ (g)(2); Proposed Treas. Reg. $\$ 53.4942(\mathrm{a})-3$ (b), 36 Fed. Reg. $11040-4 \mathrm{I}$ (I97I). The statute expressly includes as part of a qualified distribution administrative expenses incurred in making it, except where assets are purchased and amounts set aside. Compare INT. REv. CODE of I954 $\$ 4942(\mathrm{~g})(\mathrm{I})(\mathrm{A})$ with $\mathrm{Id}$. $\$ 4942(\mathrm{~g})(\mathrm{I})(\mathrm{B})$ and (2). This distinction appears to be maintained in the proposed Regulations. Compare Proposed Treas. Reg. $\$ 53.4942$ (a)-3(a) (i) svith Id. $\$ 53.4942$ (a) -3 (a) (ii) and (iii), 36 Fed. Reg. Iro4o (I975).

110 Regardless of the status of the grantee (whether individual, exempt organization, for-profit corporation, etc), the distribution must be a qualified one, that is, one which is a program-related investment, or one made for section $I 70$ (c)(2)(B) purposes. The language of that section is virtually identical to the language of section 501 (c) (3). See text accompanying note II3 supra. Neither the statute nor the regulations further explains these distributions, with the apparent result that a private foundation will be confronted with the difficult task of determining whether each grant (or other distribution) made by it satisfies the generally-phrased standards of section 4942 and its Regulations.
} 
in fact has occurred. The practical consequence for a CDC which is a private foundation is that a donor private foundation may be hesitant to make a grant to it because by doing so the donor may feel that it will be increasing its own difficulties under section 4942. The following discussion attempts to determine whether the typical CDC will be able to avail itself of the operating foundation exception.

Private foundations which are also operating foundations are accorded more favorable treatment than other private foundations, despite their lack of public financial support, because in various ways their assets and income are directly devoted to their exempt purposes rather than to grant-making. ${ }^{117}$ Examples offered by the Senate Report include museums, libraries, and research organizations. ${ }^{118}$ In order to qualify as an operating foundation under section 4942, an organization must make qualifying distributions which are equal to substantially all (eighty-five per cent) of its adjusted net income and which are to be used directly for the exempt purposes of the organization (the income test). ${ }^{119}$ In addition, the organization must meet one of the following three criteria: (a) substantially more than half of its assets (sixty-five per cent) must be devoted directly to the activities for which it was organized or to "functionally related" businesses, or both, or be stock in a comparable controlled corporation (the assets test); or (b) it must make qualifying distributions in an amount not less than two-thirds of the "minimum investment return" to be used directly for the exempt purposes for which it was formed (the endowment test); or (c) substantially all (eighty-five per cent) of its support, excluding investment income, must come from the general public and five or more unrelated exempt organizations with no one organization contributing more than twenty-five per cent of the support (the support test). In other words the would-be operating foundation must meet both the income test and either the assets, endowment, or support test. In attempting to meet any of the tests other than the support test, the principal task is to demonstrate that funds are distributed or assets are held directly for activities which further the exempt purpose of the aspiring operating foundation. ${ }^{120}$

Recently proposed Regulations set forth the manner in which each of the four tests may be met. To satisfy the income test, the organization must demonstrate

\footnotetext{
${ }^{117}$ SeNATE RePort 60. The definition of an operating foundation is set forth in INT. Rev. Code of r954 $\$ 4942(\mathrm{j})(3)$.

${ }^{238}$ SENATE REPORT 6r.

${ }^{220}$ INT. REv. CODE of $1954 \$ 4942(\mathrm{j})(3)(\mathrm{A})$. Substantially all was set at a minimum of $85 \%$ in the committee reports, Senate REPORT 60; H.R. REp. No. 9I-4I3, supre note roo, at 42, and the same figure was adopted in the proposed Regulations recently issued by the Service. Proposed Treas. Reg. $\$ 53.4942$ (b)-2(e), 36 Fed. Reg. I07 (r97I). The percentages in the other tests discussed in the text below were similarly incorporated by the Service from the Senate Report.

${ }^{120}$ If an organization could become an operating foundation by meeting, directly or indirectly, the income test and any one of the other three tests, then it would be easier to achieve that status than to meet the requirements of $\S 4942$. Absent the requirement of directness, to become an operating foundation an organization would only have to distribute substantially all ( $85 \%$ ) of its income (the income test) and not less than two-thirds of its minimum investment return (the assets test). But section 4942 requires an organization to distribute all of its income, or a sum equal to $100 \%$ of its minimum investment return, whichever is higher.
} 
that it is making qualifying distributions "directly for the active conduct of the activities constituting the purpose or function for which it is organized and operated [in an amount] equal to substantially all [eighty-five per cent] of its adjusted net income."121 Qualifying distributions are elsewhere defined in section 4942 as program-related investments and as those made to accomplish, among others, charitable, scientific, literary, or educational purposes. ${ }^{122}$ A distribution will be considered to have been made directly if the organization uses the distribution itself or if it makes a distribution to individuals or other organizations and continues to maintain a "significant involvement" in the recipient. ${ }^{123}$

It has already been noted that the typical CDC will usually distribute, directly or indirectly, all of its adjusted gross income. There is even less likelihood, of course, that the CDC will not distribute the smaller percentage (eighty-five per cent) of its adjusted gross income required by the income test. Rather, the question will be whether it distributes that percentage "directly." If the CDC is putting enough money into businesses which it is operating itself, then it will meet the requirement of "directness." In some instances, however, a CDC may avoid generating businesses within its own corporate shell by choosing instead to utilize subsidiaries or other organizations. ${ }^{124}$ In such cases the "significant involvement" test will have to be met. In most instances a CDC should be able to meet the criteria for significant involvement set forth in the Regulations; it will have (I) developed expertise, (2) maintained a staff which offers support for the uses to which the distributions are put, and (3) encouraged others to become involved in the organization's area of interest. The numerous examples set forth in the Regulations suggest that an organization will be deemed significantly involved if it performs functions other than that of merely screening distributions.

A CDC which can satisfy the income test will likely be able to meet the endowment test as well, since the same considerations are involved. An exception is that the CDC must expend an amount equal to two-thirds of its minimum investment return, rather than substantially all of its adjusted net income. ${ }^{125}$ In the rare instance where this proves not to be the case, ${ }^{126}$ the $\mathrm{CDC}$ might be able to meet the assets test, which requires that at least sixty per cent of the CDC's assets

\footnotetext{
${ }^{121}$ Proposed Treas. Reg. $\$ 53.4942$ (b)-2(a), 36 Fed. Reg. I07 (1971).

${ }^{122}$ INT. REV. CODE OF I954 $\$ 4942(\mathrm{~g})$. The definition of a qualifying distribution for an operating foundation, however, is slightly more restrictive in that the twelve month "pass-through" device cannot be used by operating foundations to make a qualifying distribution. See INT. REv. CODE of I954 $\$ 4942$ (j) (3) (A) and (B) (ii). "Pass-throughs" are discussed in text accompanying notes 128-31 infra.

${ }_{123}$ Proposed Treas. Reg. $\$ 53.4942(\mathrm{~b})-2(\mathrm{~b})$ and (c), 35 Fed. Reg. 107-08 (I97 I).

${ }^{124}$ It might be possible for a CDC to argue that funds distributed to controlled subsidiaries were in effect used by it. The proposed Regulations, however, do not discuss this possibility. See Proposed Treas. Reg. $\$ 53.4942$ (b)-2(b)(I)(i), 36 Fed. Reg. 107 (I97I).

${ }_{125}$ Proposed Treas. Reg. $\$ 53.4942$ (b) $-4,36$ Fed. Reg. Iro-II (r97I).

${ }^{120}$ This would be so only where the adjusted net income of the CDC was extremely small, since two-thirds of the minimum investment return (assuming the return is at $6 \%$ ) is only $4 \%$, and that percentage is calculated only on those net assets not directly used for exempt purposes. INT. REv. ConE OF $1954 \S 4942(\mathrm{e})$.
} 
are being used by it or its controlled subsidiaries for exempt purposes. The only test which should create difficulty for the average CDC is the support test, which requires that at least five organizations and the general public support the $\mathrm{CDC}$, with no one organization accounting for more than twenty-five per cent of all support. It is not enough, of course, for the organization to believe that it is an operating foundation; other organizations will demand evidence that the Service has made this determination. The Regulations recently proposed set forth four ways by which an organization may attempt to secure this determination from the Service. ${ }^{127}$

If a CDC were found to be a private foundation and not an operating foundation, what additional burdens would be placed on the $C D C$ and a grantor private foundation in making a qualifying distribution to the CDC? The CDC would itself have to redistribute or "pass through" the grant for qualified purposes in the taxable year after receiving it. In addition, it could not redistribute the income to another private foundation. The grantor private foundation would be required to verify that the CDC had in fact done so through "adequate records or other sufficient evidence."

The principal disadvantage to a CDC in obtaining a grant would simply be that it would have to redistribute it; the option to utilize the funds directly for its own activities would be foreclosed. Other than utilizing the funds itself or in any operations controlled by it, ${ }^{129}$ however, the CDC would be free to dispose of the funds-for qualified purposes and not to another private foundation-as it liked. From the grantor's viewpoint it may even be an advantage for it to make a grant to another private foundation, since it allows the grantor to make the grant without ascertaining that it is for qualified purposes until the donee redistributes it. The grantor consequently will have a twelve-month grace period during which it can decide on a proper qualified purpose. ${ }^{130}$ Noting that this twelve-month "passthrough" provision was a "significant exception" to the purposes of section 4942, the Senate Report explained, somewhat unconvincingly, that it "believed that this was necessary to provide adequate flexibility in operations for private foundations." ${ }^{\text {"131 }}$

\section{B. The Expenditure Responsibility Provisions}

The "expenditure responsibility" provisions may also indirectly affect CDC's because of their impact on the policies and procedures of grantor private founda-

\footnotetext{
${ }^{127}$ Proposed Treas. Reg. $\$ 53.4942$ (b) $-6,36$ Fed. Reg. III (I97I).

${ }^{128}$ If notions of adequacy of record-keeping found elsewhere in the Act can be taken as guideposts, a grantor private foundation should easily be able to satisfy its responsibilities. INT. REv. CODE of I954 $\$ 494^{2}(\mathrm{~g})(3)(\mathrm{B})$. See text accompanying notes $132-33$ infra, and particularly the language from the Senate Report quoted there.

220 Aithough the term "controlled" is used in section 4942 , it is not defined. If the definition of section $368(\mathrm{c})$ is applicable, then the standard of control would be $80 \%$. of all classes of voting stock.

${ }^{130}$ The grantor would have to ensure, of course, that it conditioned the grant so that it could reserve some power over the "pass-through." The most inoffensive manner of doing so would probably be a "sign-off" or veto power. The power to direct the grant in the absence of a veto would give the grantee a reason to serve as the pass-through when it could not use the grant itself.

181 Senate Report 37.
} 
tions. The provisions, designed to ensure that grants are expended for exempt purposes, should create few problems, however, because their requirements are set forth with considerable clarity in both the Senate Report and the recently issued proposed Regulations. ${ }^{132}$

Where both the grantor and the grantee are private foundations, section 4945 (h) requires that the grantor must "exert all reasonable efforts and . . . establish adequate procedures ( $\mathrm{I}$ ) to see that the grant is spent solely for the purpose for which made, (2) to obtain full and complete reports from the grantee on how the funds are spent, and (3) to make full and detailed reports with respect to such expenditures to the Secretary or his delegate." The emphasized language implies, and the Senate Report and the proposed Regulations confirm, that no absolute liability is to be imposed on the grantor, but rather that a "prudent man" standard is to be employed. The contents of this standard are set forth at length in the Senate Report:

It is contemplated that a [private] foundation will be required to specify the purposes of any grant clearly in the terms of the grant itself. The terms of the grant should, also, state plainly the limitations upon the recipient's use of the grant. After the grant is made, the granting foundation must take reasonable steps (a) to secure reports from the grantee on its use of the funds, and (b) to report to the Internal Revenue Service the amount and purposes of the grant, the identity of the grantee and the data which the grantor obtains on the grantee's use of the funds. The Internal Revenue Service is expected to provide an appropriate schedule or attachment for the annual information return, so that all reports which a grantmaking foundation must make to the Internal Revenue Service for I year can be consolidated in the foundation's information return for that year. If the grantor discovers a misapplication of the funds by the grantee, it would normally be required to withhold any further payments to the grantee (to the extent that it is legally able to do so) until the misapplication has been corrected, or adequate assurance pro vided that it will not occur again. Where a grantor foundation adheres to these rules, and a misuse occurs which it has no reasonable means of correcting, it will be deemed to have discharged all responsibilities under this section by reporting the default to the Internal Revenue Service. ${ }^{133}$

"Expenditure responsibility," in sum, should entail no more work than that formerly assumed voluntarily by some foundations.

\section{SUMMARY}

The impact of the private foundation provisions of the Tax Reform Act on community development corporations may be summarized as follows. If one-third or more of a CDC's financial support comes from public sources (the government, the general public, or other public charities), it will be considered a public charity under

\footnotetext{
${ }^{182}$ INT. Rev. CODE OF I954 $\$ 4945$ (d) (4) and (h). See also Senate Report 50-5I; Proposed Treas. Reg. $\$ 53.4945-5,36$ Fed. Reg. 5365 (r971).

${ }^{13}$ SENATE Report 51 . This language has been followed and elaborated in the proposed Regulations and confirms that a grantor acting in the prescribed manner will be able to avoid taxation. Proposed Treas. Reg. $\$ 53.4945-5,36$ Fed. Reg. 5365 (r97I).
} 
either of two public financial support tests. Even without such public financial support, a CDC responsive to a genuinely broad-based membership should also be considered a public charity under the facts and circumstances test. Under proposed Regulations, this test requires only that ten per cent of a CDC's support be public support if the CDC's public nature can be otherwise demonstrated. Lastly, under both the facts and circumstances test and one of the public financial support tests, provision is made for the exclusion of unusual grants. By making use of this exclusion, a CDC may be able to reduce substantially the amount of private contributions includable in total support, and thus increase the possibility that the amount of its public support will equal or exceed the percentages required to meet either of the two tests.

If a CDC is considered a private foundation, it will have to guard against the imposition of taxes on self-dealing, and may confront problems in attempting to maintain sizeable business holdings. Most holdings, however, should come within the exceptions to the section setting forth the taxes on excess holdings for programrelated investments. In light of the proposed Regulations recently issued by the Service, this exception should cover the investments of CDC's which are not purely commercial.

Other provisions may also offer some difficulties, though hopefully they will be little more than nuisances. The CDC will be forced to avoid certain activities which might be classified as taxable expenditures. As a potential grantee, it may also indirectly feel the impact of the provisions taxing the failure to distribute income and to exercise expenditure responsibility. In the long run, these should only be significant where the grantor-private foundation is overly cautious in establishing its own operating policies. The CDC will also probably find its paperwork increased by the Act's expansion of the reporting requirements imposed both on all exempt organizations and on private foundations.

If a CDC does not yet have an exemption, it should carefully consider the potential adverse impact of the private foundation provisions before submitting its exemption application. A CDC already possessing the exemption, in contrast, has little choice but to live with the provisions, if it is in fact a private foundation, since the methods of terminating private foundation status are of little practical value to it. ${ }^{134}$

${ }^{136}$ The Tax Reform Act of 1969 permits a private foundation to terminate its private foundation status by either of two basic methods. It may transfer its assets to a public charity, or it may begin and continue to operate as a public charity itself. These methods have since been spelled out by the Service in recently issued temporary Regulations. T.D. 7063 , r970 INT. Rev. BuLL. No. 44, at 8, as amended by T.D. 7085, I97I INT. REv. BuLL. No. 5, at I4. The possibility of terminating by either method will probably be of little practical importance to a CDC. By pursuing the first method (transferring its assets to a public charity), the $\mathrm{CDC}$, of course, would be putting itself out of business. Since the CDC can probably live with private foundation status, it is obviously much worse off in terminating its status in this way especially if there was a substantial likelihood, in the opinion of the CDC prior to its attempt to obtain a section $\operatorname{5or}(\mathrm{c})(3)$ exemption, that it would be designated a private foundation. Were the CDC to wish to terminate such private foundation status, the initial decision should therefore be not to seek such exemption but to remain a nonprofit corporation. The second method available to 
the $\mathrm{CDC}$ to end private foundation status would be to begin operating as a public charity. In doing so, however, it would find itself confronting roughly the same problems obtaining designation as a public charity as would a recently formed CDC which had just applied for an exemption and was seeking to avoid private foundation status. A CDC that finds itself a private foundation is likely to have recently obtained that status, so attempting to terminate it would in effect be an attempt to reopen a determination just made, and the result is likely to be the same. 